\title{
Reduction of the number of cylinders in internal combustion engines - contemporary trends in downsizing
}

\begin{abstract}
The article presents the possibility of reduction of the $\mathrm{CO}_{2}$ emission due to application of downsizing, resulting also in the reduction in fuel consumption by engines. From 2015, carbon dioxide emissions will be limited to $130 \mathrm{~g} / \mathrm{km}$. Due to this there has been observed an increase in the number of three-cylinder combustion engines on the offer of most global automotive companies. In the article are presented selected new designs of three-cylinder engines, with focus on their performance parameters. The static and dynamic downsizing has been defined as the contemporary direction of the development of combustion engines. In the article are also suggested indexes of static and dynamic downsizing and their interdependency for the considered combustion engines.
\end{abstract}

Key words: combustion engine, static downsizing, dynamic downsizing, downsizing indexes

\section{Ograniczenie liczby cylindrów w silnikach spalinowych - współczesny kierunek rozwoju downsizingu}

\begin{abstract}
$W$ artykule przedstawiono możliwości ograniczenia emisji $\mathrm{CO}_{2}$ dzięki zastosowaniu dowsizingu, co umożliwia zmniejszenie zużycia paliwa przez silniki. Od roku 2015 poziom emisji dwutlenku węgla będzie limitowany do $130 \mathrm{~g} / \mathrm{km}$. W związk z tym obserwuje się zwiększenie liczby trzycylindrowych silników spalinowych w ofertach większości światowych koncernów motoryzacyjnych. Zaprezentowano wybrane, nowe konstrukcje silników trzycylindrowych w aspekcie wskaźników pracy tych jednostek. Zdefiniowano downsizing statyczny i dynamiczny jako współczesny kierunek rozwoju silników spalinowych. Zaproponowano wskaźniki downsizingu statycznego i dynamicznego dla rozpatrywanych silników spalinowych.
\end{abstract}

Słowa kluczowe: silnik spalinowy, downsizing statyczny, downsizing dynamiczny, wskaźniki downsizingu

\section{Introduction}

Over the past few years there has been a significant reduction of carbon dioxide emissions from passenger vehicles sold in the European Union. The reason contributing to this is the process of downsizing of combustion engines (reduction of engine displacement while maintaining the same or increased operating parameters, increase in the share of engines fueled with alternative fuels and increase in the share of alternative-powered vehicles, including electric) $[1,14,16]$.

As part of the greenhouse gas emission reduction strategy, in 2007 the European Union introduced limits on carbon dioxide emissions for new passenger cars. The European Environment Agency (EEA) supports the European Commission in monitoring the $\mathrm{CO}_{2}$ emissions from passenger vehicles in accordance with EC Regulation 443/2009. This regulation determines reduction of carbon dioxide emissions to $130 \mathrm{~g} / \mathrm{km}$ in 2015. This value is defined as the average for the fleet of newly registered vehicles of each manufacturer. This objective has been gradually implemented since 2012 .

In 2012, the biggest vehicle manufacturers (registrations of more than 100,000 new vehicles) sold about 11.4 million vehicles in the countries of the European Union, which represents approximately $94.5 \%$ of new registrations [4]. The average emissions of $\mathrm{CO}_{2}$ from those vehicles amounted to $130.4 \mathrm{~g} / \mathrm{km}$, meaning only $1.8 \mathrm{~g}$ of $\mathrm{CO}_{2}$ less than for the entire fleet.

\section{Wprowadzenie}

W ciągu ostatnich kliku lat nastąpiło znaczne ograniczenie emisji dwutlenku węgla z pojazdów osobowych sprzedawanych w Unii Europejskiej. Przyczynia się do tego downsizing silników spalinowych (ograniczenie objętości silników przy zachowaniu tych samych lub zwiększonych parametrów ich pracy, zwiększenie udziału silników o zasilaniu paliwami alternatywnymi oraz zwiększenie udziału pojazdów o napędzie alternatywnym, w tym elektrycznym) $[1,14,16]$.

W ramach strategii ograniczania emisji gazów cieplarnianych Unia Europejska w 2007 roku. wprowadziła limity emisji dwutlenku węgla dla nowych samochodów osobowych. Europejska Agencja Środowiska (EEA) wspiera Komisję Europejską w monitorowaniu emisji $\mathrm{CO}_{2}$ z pojazdów osobowych zgodnie $\mathrm{w}$ rozporządzeniem EC 443/2009. Rozporządzenie to ustanawia poziom emisji dwutlenku węgla do wartości $130 \mathrm{~g} / \mathrm{km}$ w 2015 roku. Wartość tę definiuje się jako średnią z floty pojazdów każdego z producentów nowo zarejestrowanych pojazdów samochodowych. Jest to wprowadzane stopniowo od 2012 roku.

Najwięksi producenci pojazdów (rejestracje nowych pojazdów - ponad 100000 sztuk) sprzedali w 2012 roku około 11,4 miliona pojazdów w krajach Unii Europejskiej, co stanowi około 94,5\% nowych rejestracji [4]. Średnia emisja 
In 2012 eight large manufacturers of vehicles (Fiat, Renault, Peugeot, Toyota, Citroën, Seat, Ford, Kia) showed the average carbon dioxide emissions below $130 \mathrm{~g} / \mathrm{km}$ (in 2011 - only six). Emission values for those manufacturers are quite diverse and range from $117 \mathrm{~g} \mathrm{CO}_{2} / \mathrm{km}$ to $143 \mathrm{~g} \mathrm{CO}_{2} / \mathrm{km}$.

The values of carbon dioxide emissions presented above are inextricably associated with fuel consumption. Reduction of fuel consumption is possible due to the development of new designs of injection systems [10], supercharging systems for engines [2], the use of hybrid drives [1] and exhaust gas recirculation systems [3]. This is, among others, the result of downsizing: reduction of engine displacement while increasing the power/displacement ratio. It is anticipated that a stronger tendency to limit the number of cylinders will be developed, as the forecasts indicate the most intensive growth

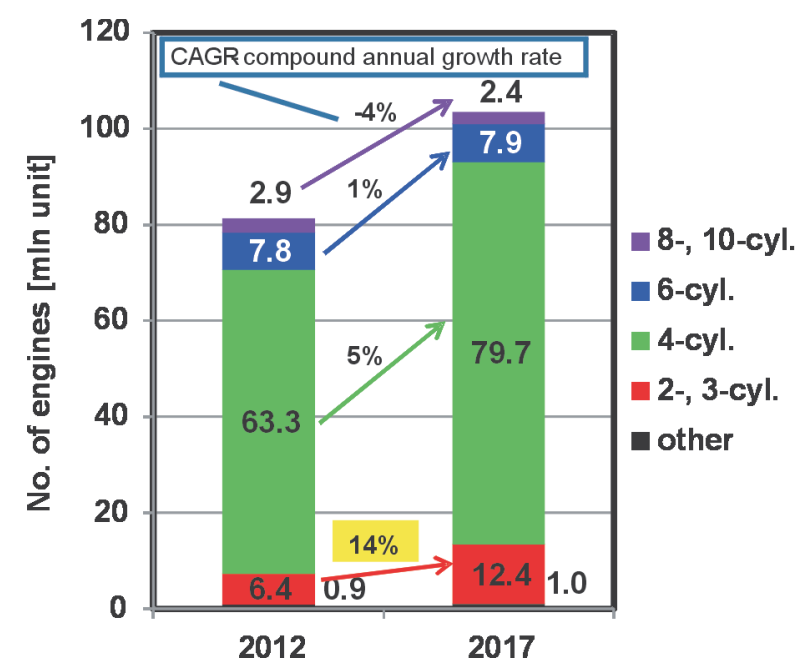

Fig. 1. The number of engines produced and changes in the number of cylinders over a period of a few years [15]

Rys. 1. Liczba produkowanych silników i zmiany liczby cylindrów na przestrzeni kilku lat [15]

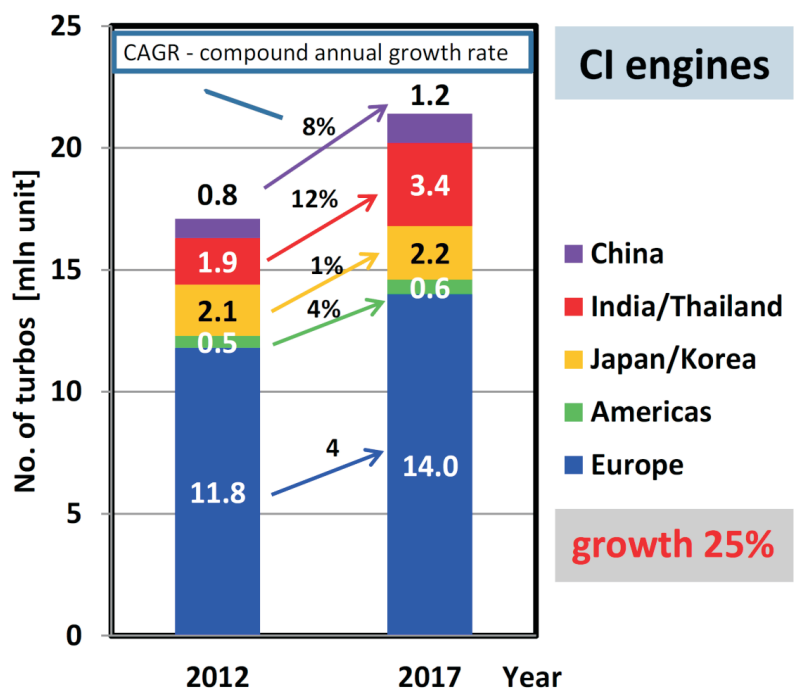

$\mathrm{CO}_{2}$ z pojazdów tych producentów wyniosła $130,4 \mathrm{~g} / \mathrm{km}$, co oznacza tylko $1,8 \mathrm{~g} \mathrm{CO}_{2}$ mniej niż z całej floty.

W roku 2012 pojazdy ośmiu dużych producentów (Fiat, Renault, Peugeot, Toyota, Citroën, Seat, Ford, Kia) miały średnią emisją dwutlenku węgla poniżej 130 g/km (w $2011 \mathrm{r}$. tylko sześciu). Emisja z pojazdów tych producentów jest dość zróżnicowana i wynosi od 117 g CO$/ 2 / \mathrm{km}$ do $143 \mathrm{~g} \mathrm{CO}_{2} / \mathrm{km}$. Te wielkości emisji dwutlenku węgla nierozerwalnie są związane ze zużyciem paliwa. Ograniczenie zużycia paliwa jest możliwe dzięki opracowaniu nowych konstrukcji układów wtryskowych [10], systemów doładowania silników [2], stosowaniu napędów hybrydowych [1] oraz systemów recyrkulacji spalin [3]. To natomiast jest efektem m.in. ograniczenia objętości skokowej silników przy jednoczesnym zwiększeniu stopnia ich wysilenia - downsizingu. Przewiduje się, że tendencje do ograniczania liczby cylindrów będą coraz większe, gdyż prognozy zwiększenia produkcji silników 2- i 3-cylindrowych wskazują na ich największą intensywność przyrostu. Z analiz firm IHS Automotie oraz BorgWarner [16] wynika, że roczne zwiększanie liczby tych silników będzie wynosiło 14\% (rys. 1). Jest to największa wartość spośród analizowanych jednostek napędowych. Stwierdzono także, że udział silników 2-, 3- i 4-cylindrowych wyniesie około 99\% w całkowitej produkcji silników w latach 2012-2017. Downsizing bez systemów doładowania nie ma istotnego znaczenia. Ma to swoje odzwierciedlenie w liczbie pojawiających się na rynku dostępnych silników o zapłonie samoczynnym (typowe już rozwiązania) i iskrowym z układami turbodoładowania. Zakłada się, że w ciągu najbliższych kilku lat roczny przyrost tych ostatnich rozwiązań wyniesie około $20 \%$ (rys. 2).

\section{Przykłady silników 3-cylindrowych}

Opisane zwiększenie liczby silników 3-cylindrowych ma odzwierciedlenie w ofercie poszczególnych koncernów motoryzacyjnych. Producenci wprowadzają silniki 3-cylindrowe głównie do mniejszych, typowo miejskich

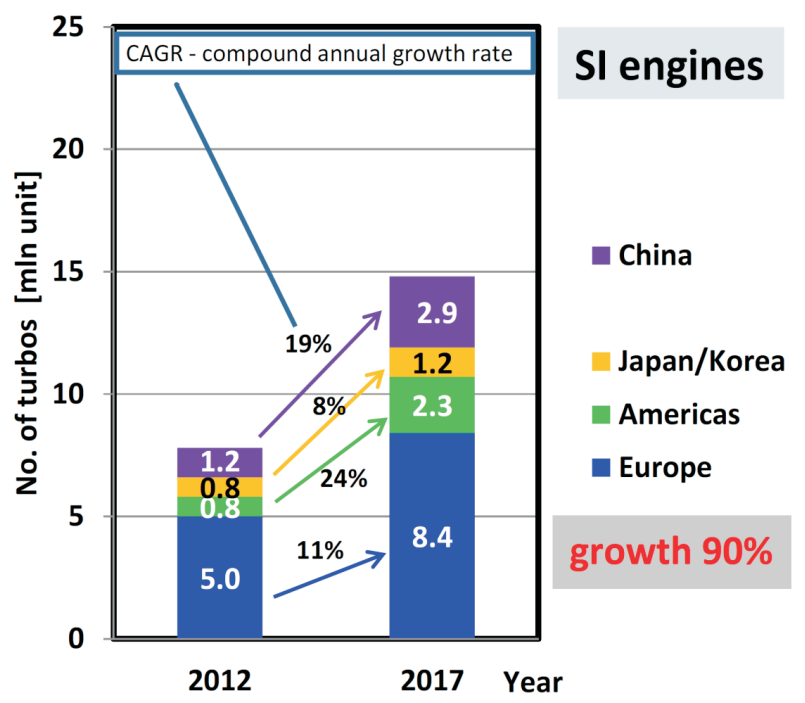

Fig. 2. The number of produced compression ignition and spark ignition engines with turbo-charging systems [15] Rys. 2. Liczba produkowanych silników ZS i ZI wyposażonych w układy turbodoładowania [15] 
Table 1. Selected 3-cylinder engines offered by vehicle manufacturers [5-7, 12, 17-23, 25]

Tabela 1. Wybrane silniki 3-cylindrowe oferowane przez producentów pojazdów [6-8, 12, 17-23, 25]

\begin{tabular}{|c|c|c|c|c|c|c|c|c|}
\hline $\begin{array}{c}\text { Manufacturers/ } \\
\text { producent }\end{array}$ & $\begin{array}{l}\text { Model/ } \\
\text { model }\end{array}$ & $\begin{array}{l}\text { Engine/ } \\
\text { silnik }\end{array}$ & $\left.\begin{array}{c}\mathrm{V}_{\mathrm{ss}} \\
{\left[\mathrm{dm}^{3}\right]}\end{array}\right]$ & $\begin{array}{c}\mathrm{S} \times \mathrm{D} \\
{[\mathrm{mm} \times \mathrm{mm}]}\end{array}$ & $\begin{array}{c}\mathrm{N}_{\mathrm{e}} \\
{[\mathrm{kW} / \mathrm{rpm}]}\end{array}$ & $\begin{array}{c}\mathrm{M}_{\mathrm{o}} \\
{[\mathrm{N} \cdot \mathrm{m} / \mathrm{rpm}]}\end{array}$ & $\begin{array}{c}\mathrm{N}_{\mathrm{V}} \\
{\left[\mathrm{kW} / \mathrm{dm}_{3}\right]}\end{array}$ & $\begin{array}{c}p_{e} \\
{[\mathrm{MPa}]}\end{array}$ \\
\hline \multirow[t]{2}{*}{ BMW, MINI } & $\begin{array}{l}2 \text { Active } \\
\text { Tourer, One } \\
\text { Cooper }\end{array}$ & SI DI Turbo & 1.499 & $82 \times 94.6$ & $\begin{array}{c}100 / \\
4400-6000\end{array}$ & $\begin{array}{c}220 / \\
1250-4300\end{array}$ & 66.7 & 1.84 \\
\hline & $\begin{array}{c}\text { One D, } \\
\text { Cooper D }\end{array}$ & CI DI Turbo & 1.496 & $84 \times 90$ & $85 / 4000$ & $270 / 1750$ & 56.8 & 2.27 \\
\hline FORD & Fiesta & SI DI Turbo & 0.999 & $71.9 \times 82$ & $74 / 5500$ & $\begin{array}{c}170 / \\
1400-4000\end{array}$ & 74.1 & 2.14 \\
\hline $\begin{array}{l}\text { KIA, HY- } \\
\text { UNDAI }\end{array}$ & Picanto, i10 & SI MPI & 0.998 & $71 \times 84$ & $60.3 / 6300$ & $95 / 3500$ & 60.4 & 1.20 \\
\hline MAHLE & $\begin{array}{l}\text { VW Passat } \\
\text { Estate }\end{array}$ & SI DI Turbo & 1.2 & $83 \times 73.9$ & $\begin{array}{c}120 / \\
5000-6000\end{array}$ & $\begin{array}{c}286 / \\
1600-3500\end{array}$ & 100 & 2.99 \\
\hline \multirow[t]{2}{*}{ MERCEDES } & Smart Brabus & SI MPI Turbo & 0.999 & $72 \times 81.8$ & $75 / 6000$ & $\begin{array}{c}147 / \\
2500-3600\end{array}$ & 75.1 & 1.85 \\
\hline & Smart & CI DI Turbo & 0.799 & $65.5 \times 79$ & $40 / 3800$ & $\begin{array}{c}130 / \\
2100-2600\end{array}$ & 50.1 & 2.04 \\
\hline NISSAN & Micra, Note & $\begin{array}{c}\text { SI DI } \\
\text { Compressor }\end{array}$ & 1.198 & $78 \times 83.6$ & $72 / 5200$ & $142 / 4400$ & 60.1 & 1.49 \\
\hline OPEL & Adam & SI DI Turbo & 0.998 & $77.4 \times 74$ & $85 / 5200$ & $\begin{array}{c}166 / \\
1800-4700\end{array}$ & 85.2 & 2.09 \\
\hline PSA & C3, 2008 & SI MPI & 1.199 & $75 \times 90.5$ & $60 / 5750$ & $118 / 2750$ & 50.0 & 1.24 \\
\hline RENAULT & Clio & SI MPI Turbo & 0.899 & $72.2 \times 73.1$ & $67 / 5250$ & $135 / 2500$ & 74.5 & 1.89 \\
\hline TOYOTA & Aygo & SI MPI & 0.998 & $71 \times 84$ & $51 / 6000$ & $95 / 4300$ & 50.1 & 1.17 \\
\hline \multirow[t]{2}{*}{ VW } & Up! & SI MPI & 0.999 & $74.5 \times 76.4$ & $55 / 6200$ & $\begin{array}{c}95 / \\
3000-4300\end{array}$ & 44.0 & 1.19 \\
\hline & Polo & CI DI Turbo & 1.199 & $79.5 \times 80.5$ & $55 / 4200$ & $180 / 2000$ & 45.9 & 1.89 \\
\hline
\end{tabular}

in the production of 2-and 3-cylinder engines. The analyses of IHS Automotie and BorgWarner [15] show that the annual increase in the number of these engines will amount to $14 \%$ (Fig. 1). It is the largest value among the analyzed drive units. In addition, a 99\% increase in the production of 2-3- and 4 -cylinder engines in years 2012-2017 is predicted. However, downsizing without supercharging systems is of negligible importance. This is reflected in the number of compression ignition engines (being already typical solutions) and spark ignition engines with turbo-charging systems available on the market. It is assumed that within the next few years the annual increase for that latter solution will be around $20 \%$ (Fig. 2).

\section{Examples of 3-cylinder engines}

The above-mentioned increase in the number of threecylinder engines is reflected in the offer of various automotive companies. The pojazdów. Tabela 1 podaje wybrane silniki dostępne w autach segmentu A. Aplikacji poszczególnych jednostek można upatrywać również w pojazdach segmentu C (np. BMW 2 Active Tourer).

Na podstawie tabeli 1 dokonano zestawienia silników spalinowych 3-cylindrowych wybranych producentów (rys. 3). Analiza rys. 3 wskazuje na znaczną dominację silników o zapłonie iskrowym. Trzycylindrowych silników o zapłonie samoczynnym na rynku silnikowym jest obecnie niewiele.

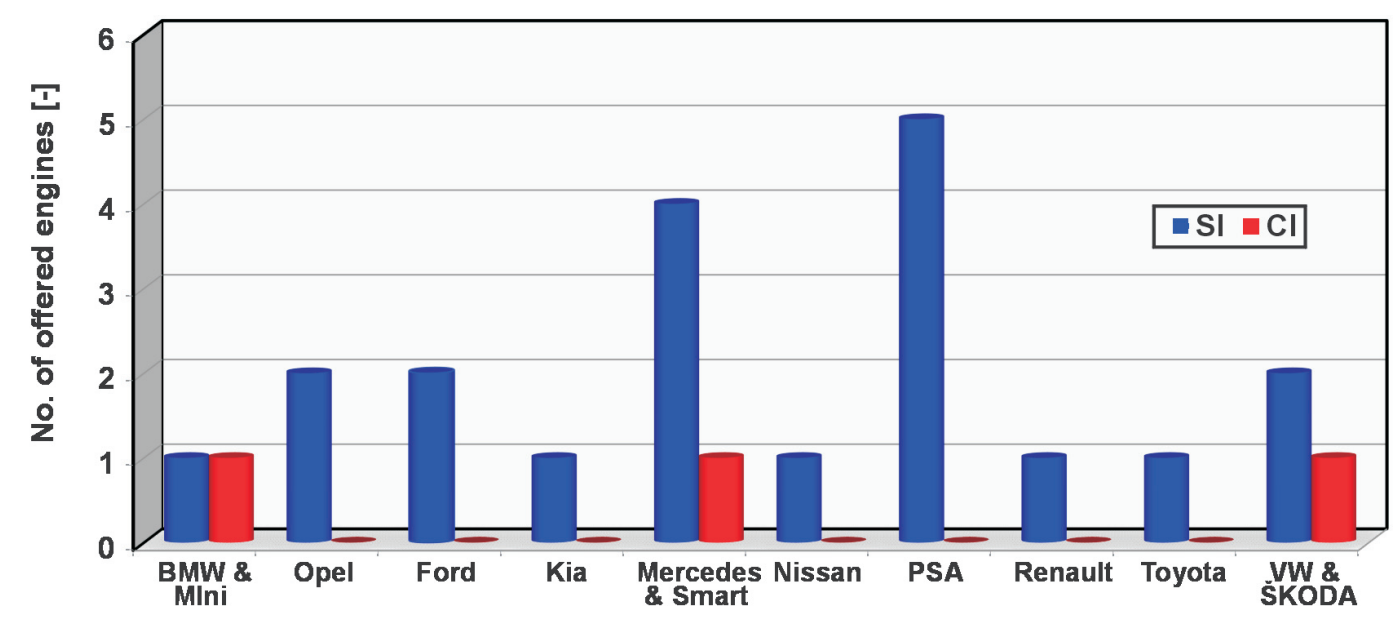

Fig. 3. Number of 3-cylinder engines offered by the selected vehicle manufacturers Rys. 3. Liczba oferowanych silników 3-cylindrowych przez wybranych producentów pojazdów 
manufacturers introduce the 3-cylinder engines mainly into smaller, typically urban vehicles. Table 1 presents selected engines available in cars of A-segment. Certain engines are also utilized in vehicles of the C-segment (e.g. BMW 2 Active Tourer).

On the basis of Table 1 an overview of 3-cylinder combustion engines of the selected manufacturers was drawn (Fig. 3). The analysis of the number of engines indicates a significant dominance of spark ignition engines. Currently there are not many 3-cylinder compression ignition engines on the market.

\section{The characteristics of 3-cylinder engines in relation to their downsizing}

The selected drive units shown in table 1 are compared to 4-cylinder engines of particular manufacturers. On this basis the analysis of the changes of operating indexes was conducted (Fig. 4): change of the maximum effective pressure and change of the operating area of engines defined by the engine speed and the maximum values of effective pressure. There are compared spark ignition engines by BMW, Opel, Ford, Nissan and Volkswagen. There are also shown compression-ignition engines by Volkswagen.

Figure 4 shows that each of the manufacturers has reduced the engine displacement while aiming at increasing the average effective pressure. The most significant growth of $p_{e}$ is observed for supercharged engines replacing the normally aspirated engines. The BMW 1.5 DI TwinPower Turbo engines (increasing $\mathrm{p}_{\mathrm{e}}$ by $47 \%$ ), Opel 1.0 SIDI (78\%), Ford EcoBoost (81\%) and Renault 0.9 Turbo MPI (63\%) supercharged with the use of turbochargers show the most significant changes in the value of average effective pressure. There is also observed flatter characteristics of the effective pressure $\mathrm{p}_{\mathrm{e}}$ for turbocharged engines. In case of the Nissan 1.2 DI engine supercharged with the use of mechanical compressor there has been reached $20 \%$ increase in the value of $p_{e}$ in relation to $p_{e}$ of the previous engine. Increase of the average effective pressure in case of VW engines amounts only to $4 \%$. This value applies to both CI and SI engines subjected to downsizing. The analysis of the operating areas of the selected combustion engines shows that the percentage increase of the power/displacement ratio of those engines is equal to the percentage increase of their operating areas. In some cases of downsizing the maximum engine speeds were reduced (Opel 1.0 SIDI, Nissan 1.2 DI), but this is not common for the majority of combustion engines.

\section{Indexes of combustion engines performance}

The engines subjected to downsizing are compression ignition or spark ignition engines, among which there are normally aspirated engines or engines charged with turbocharger or mechanical compressor. Compression-ignition engines are charged with turbochargers. Therefore, their performance characteristics and interdependence of engine torque and power differ. However, the basic division taken into account was the division into 4-cylinder engines and their 3-cylinder replacements.

\section{Charakterystyki silników 3-cylindrowych w aspekcie ich downsizingu}

Wybrane jednostki napędowe przedstawione w tabeli 1 zestawiono z jednostkami czterocylindrowymi poszczególnych producentów. $\mathrm{Na}$ tej podstawie dokonano analizy zmiany wskaźników pracy (rys. 4): maksymalnego ciśnienia użytecznego oraz zmiany wielkości pola pracy silników określonego prędkością obrotową oraz maksymalnymi wartościami ciśnienia użytecznego. Zestawiono ze sobą i porównano silniki o zapłonie iskrowym firmy BMW, Opel, Ford, Nissan oraz Volkswagen. Dodatkowo przedstawiono również jednostki o zapłonie samoczynnym firmy Volkswagen.

$\mathrm{Z}$ analizy rysunku 4 wynika, że każdy z producentów zmniejszył objętość skokową silnika, dążąc jednocześnie do zwiększenia średniego ciśnienia użytecznego. Największy przyrost $\mathrm{p}_{\mathrm{e}}$ jest zauważalny dla silników doładowanych zastępujących silniki wolnossące. Jednostki BMW 1.5 DI TwinPower Turbo (zwiększenie $\mathrm{p}_{\mathrm{e}}$ o 47\%), Opel 1.0 SIDI (78\%), Ford EcoBoost (81\%) oraz Renault 0.9 Turbo MPI (63\%) doładowane za pomocą turbosprężarek mają największe zmiany wartości średniego ciśnienia użytecznego. Zauważalny jest także bardziej płaski przebieg ciśnienia użytecznego $\mathrm{p}_{\mathrm{e}}$ dla jednostek turbodoładowanych. Dla silnika 1.2 DI firmy Nissan doładowanego za pomocą sprężarki mechanicznej osiągnięto 20-procentowe zwiększenie wartości $\mathrm{p}_{\mathrm{e}} \mathrm{w}$ stosunku do $\mathrm{p}_{\mathrm{e}}$ poprzedniego silnika. Zwiększenie średniego ciśnienia użytecznego dla silników VW wynosi tylko 4\%. Wartość ta dotyczy zarówno silników ZI, jak i ZS poddanych downsizingowi. Analiza pól pracy analizowanych silników spalinowych pozwala na stwierdzenie, że procentowy przyrost wysilenia tych jednostek jest równy procentowemu zwiększeniu pola ich pracy. W niektórych przypadkach downsizingu ograniczono maksymalną prędkość obrotową silników (Opel 1.0 SIDI, Nissan 1.2 DI), jednak nie jest to tendencja, która dotyczy większości silników spalinowych.

\section{Wskaźniki pracy silników spalinowych}

Przedstawione jednostki poddane downsizingowi to silniki o zapłonie iskrowym oraz samoczynnym, występujące jako wolnossące lub doładowane turbosprężarką albo sprężarką mechaniczną. Silniki o zapłonie samoczynnym występują jako doładowane turbosprężarkami, dlatego ich charakterystyki pracy oraz zależności momentu obrotowego i mocy różnią się. Jednak podstawowym podziałem, na jaki zwrócono uwagę, jest podział na silniki czterocylindrowe oraz zastępujące je jednostki trzycylindrowe.

Na rysunku 5 przedstawiono wartości momentu obrotowego w zależności od objętości skokowej silnika. Trzycylindrowe jednostki ZS uzyskują niewiele większe wartości momentu obrotowego przy nieznacznie mniejszej objętości skokowej silnika. Znaczne różnice uzyskano dla silników benzynowych. Dzięki dużemu udziałowi doładowanych silników trzycylindrowych ZI wartości momentu obrotowego są znacznie większe od ich niedoładowanych odpowiedników przy zmniejszonej objętości skokowej. 

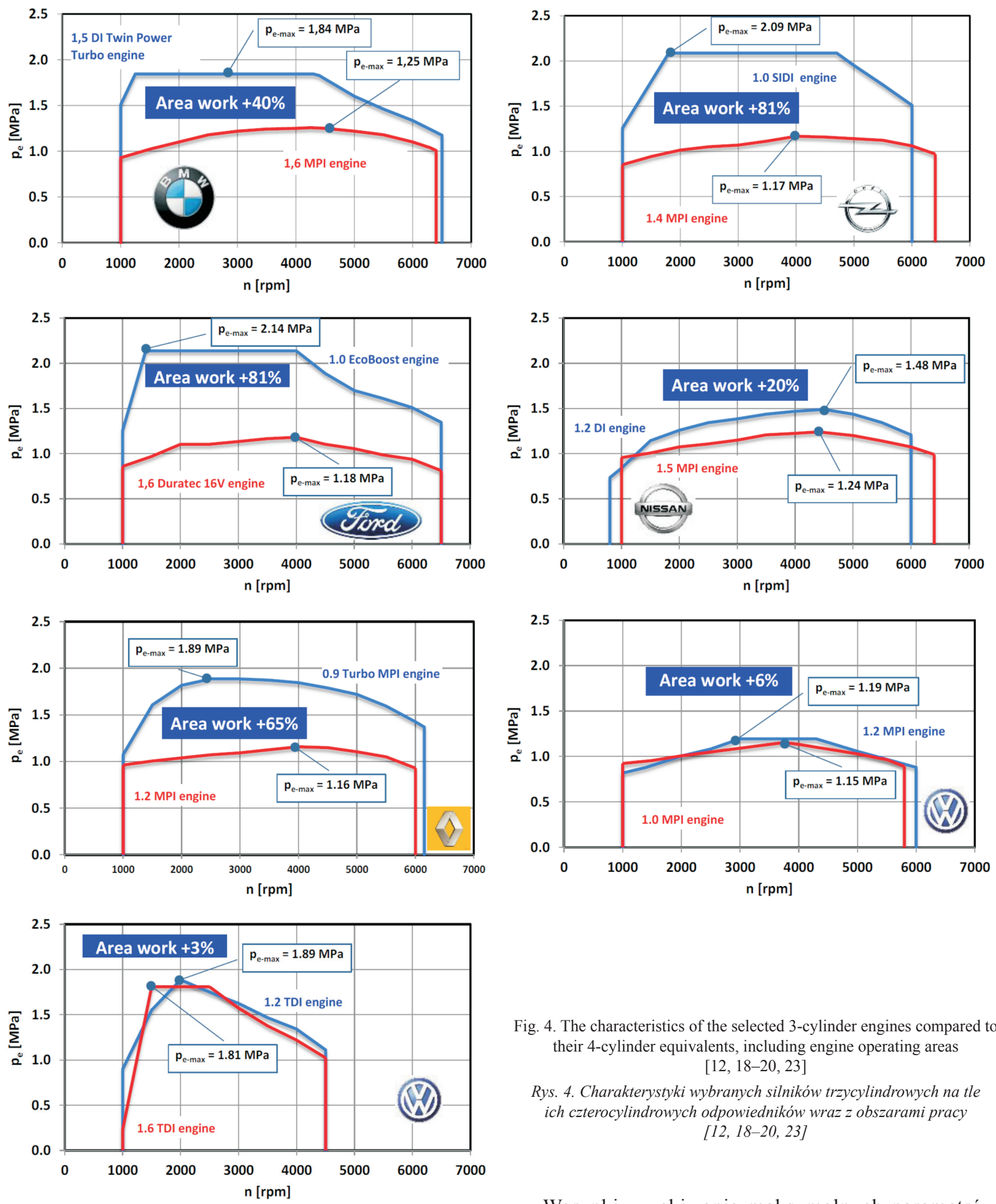

Figure 5 shows the values of engine torque in relation to engine displacement. The 3-cylinder CI engines achieve values of torque not much higher at a slightly lower engine displacement. Significant differences were obtained for gasoline engines. Due to significant share of supercharged 3-cylinder CI engines the values of engine torque are much higher at a reduced engine displacement.

Fig. 4. The characteristics of the selected 3-cylinder engines compared to their 4-cylinder equivalents, including engine operating areas [12, 18-20, 23]

Rys. 4. Charakterystyki wybranych silników trzycylindrowych na tle ich czterocylindrowych odpowiedników wraz z obszarami pracy $[12,18-20,23]$

Warunki uzyskiwania maksymalnych parametrów pracy silnika przedstawiono na rys. 6. Odnotowano wartości mocy maksymalnych analizowanych silników o ZS (3- i 4-cylindrowych) w przedziale 40-80 kW (moment obrotowy z przedziału 130-270 N·m). Wskazano, że odpowiednie wartości występują przy zbliżonych prędkościach obrotowych. Maksymalny moment obrotowy dla silników o ZS występuje przy około $2000 \mathrm{obr} / \mathrm{min}$, natomiast maksymalna moc - przy około $4000 \mathrm{obr} / \mathrm{min}$. 
The conditions for obtaining the maximum values of engine performance parameters are shown in Fig. 6. The values of maximum power of the analyzed CI engines (3- and 4-cylinder engines) in the range of $40-80 \mathrm{~kW}$ (engine torque in the range of $130-270 \mathrm{~N} \cdot \mathrm{m}$ ) were recorded. It was proved that the appropriate values occur at similar engine speeds. The maximum torque for compression ignition engines occurs at around $2000 \mathrm{rpm}$, while the maximum power occurs at about $4000 \mathrm{rpm}$.

The four-cylinder SI engines achieve maximum engine torque for engine speeds of 4000-4500 rpm and maximum power within the range of 5500-6000 rpm. In case of 3-cylinder engines the maximum values of the speed at which the maximum torque occurs are quite different and range from $1400 \mathrm{rpm}$ to $4400 \mathrm{rpm}$. BMW engines $\left(\mathrm{M}_{\mathrm{o}}=220 \mathrm{~N} \cdot \mathrm{m}\right)$ and Mahle $\left(M_{0}=286 \mathrm{~N} \cdot \mathrm{m}\right)$ obtain higher values of the torque than the 4-cylinder engines with higher displacement. This is associated with the application of supercharging. Maximum power values for 3-cylinder SI engines are in most cases close to the power values of the 4-cylinder engines (which means higher power/displacement ratio for 3-cylinder engines) and are obtained for the range of 4500-6200 rpm.

a)

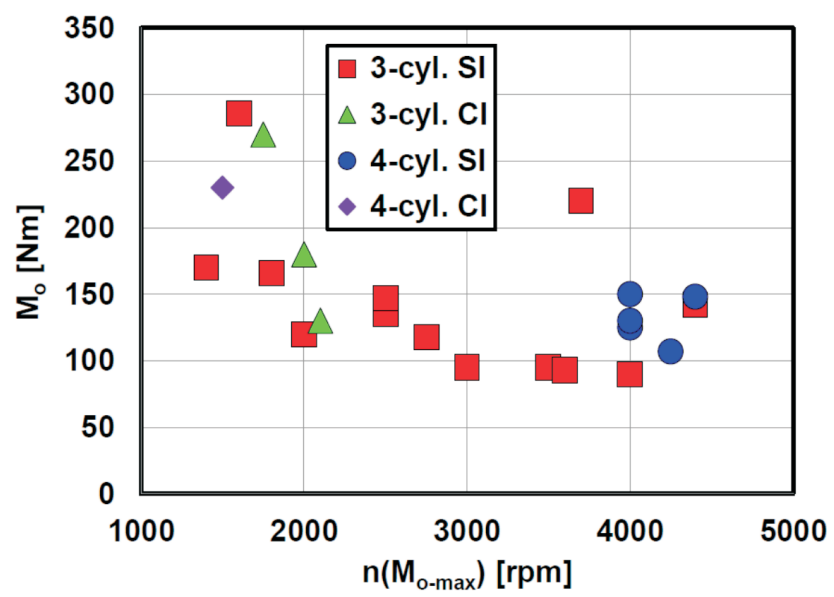

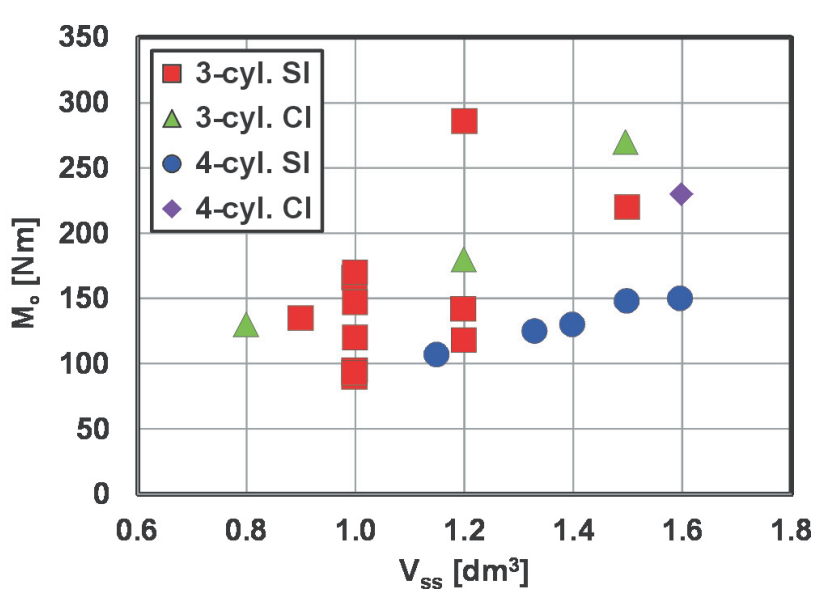

Fig. 5. Engine torque values Rys. 5. Wartości momentu obrotowego

Czterocylindrowe jednostki ZI uzyskują maksymalny moment obrotowy w zakresie prędkości obrotowych 4000-4500 obr/min oraz maksymalną moc w zakresie 5500-6000 obr/min. Dla silników trzycylindrowych maksymalne wartości prędkości, przy których występuje mob)

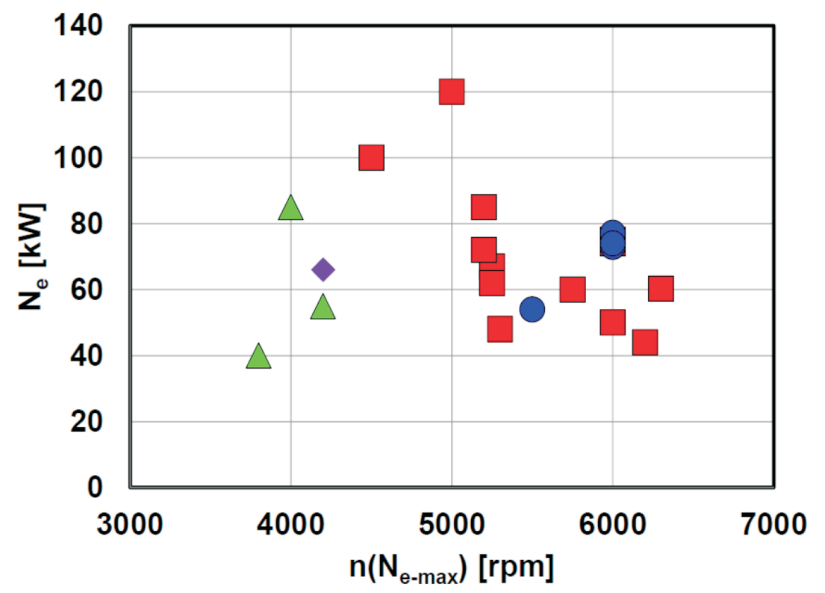

Fig. 6. Engine performance indexes: engine torque (a) and engine power (b) and the corresponding engine speeds Rys. 6. Wskaźniki pracy silnika: momentu (a) i mocy silnika (b) oraz odpowiadajace im prędkości obrotowe

In order to determine the suitability of the engine for a vehicle, it was necessary to define its flexibility. The flexibility depends on the engine characteristics and shows the engine ability to adapt to the applied loads. To determine the engine flexibility it was necessary to introduce flexibility indexes.

The first index is flexibility of the engine torque $\mathrm{e}_{\mathrm{M}}$, which is expressed by the ratio of the maximum torque $\mathrm{M}_{\mathrm{o} \max }$ to engine torque at a speed at maximum engine power $\mathrm{M}_{\mathrm{ON}}$ :

$$
\mathrm{e}_{\mathrm{M}}=\frac{\mathrm{M}_{\mathrm{o}_{\text {max }}}}{\mathrm{M}_{\mathrm{ON}}}
$$

The value of the $e_{M}$ index for combustion engines will always be higher or equal to one. A value close to one means ment maksymalny są różne i wynoszą od $1400 \mathrm{obr} / \mathrm{min}$ do $4400 \mathrm{obr} / \mathrm{min}$. Silniki BMW $\left(\mathrm{M}_{\mathrm{o}}=220 \mathrm{~N} \cdot \mathrm{m}\right)$ oraz Mahle $\left(\mathrm{M}_{\mathrm{o}}=286 \mathrm{~N} \cdot \mathrm{m}\right)$ uzyskują większe wartości momentu obrotowego niż jednostki czterocylindrowe o większej objętości. Wynika to z zastosowania doładowania. Wartości mocy maksymalnych trzycylindrowych silników ZI są w większości zbliżone do mocy jednostek czterocylindrowych (co oznacza większe wysilenie silników trzycylindrowych) i osiągane w zakresie 4500-6200 obr/min.

W celu określenia przydatności silnika do zastosowania w pojeździe określono jego elastyczność. Zależy ona od charakterystyki silnika i świadczy o zdolności jego przystosowania do zadanych obciążeń. Określenie elastyczności silnika wymagało wprowadzenia wskaźników elastyczności. Pierwszy $\mathrm{z}$ nich to elastyczność momentu obrotowego $\mathrm{e}_{\mathrm{M}}$, 
constant value the torque for engine speeds from $\mathrm{M}_{\mathrm{o} \max }$ to $\mathrm{M}_{\mathrm{oN}}$.

The flexibility of the engine speed en is an index expressed by the ratio of the engine speed at the maximum engine power $\mathrm{n}_{\mathrm{N}}$ to engine speed occurring at maximum torque $\mathrm{n}_{\mathrm{M}}$;

$$
\mathrm{e}_{\mathrm{n}}=\frac{\mathrm{n}_{\mathrm{N}}}{\mathrm{n}_{\mathrm{M}}}
$$

Its value also cannot be less than one (a value of one indicates that the maximum power occurs at the same engine speed as the maximum torque). The higher the value of this index is, the greater the range of the engine effective speeds is.

The above-mentioned indexes are presented in relation to the average effective pressure pe. The 3-cylinder CI engines replacing the 4-cylinder engines obtain higher $p_{e}$ values but lower flexibility indexes. In case of SI engines, the new 3-cylinder engines obtain higher $\mathrm{p}_{\mathrm{e}}$ and, in some cases, larger values of $e_{M}$ index (Fig. 7a). This is due to the fact that the normally aspirated engines with higher engine displacement have flatter characteristics of the torque. Despite this, the majority of 3-cylinder engines due to supercharging gain higher flexibility indexes of the engine speed $e_{n}-$ Fig. $7 b$.

a)

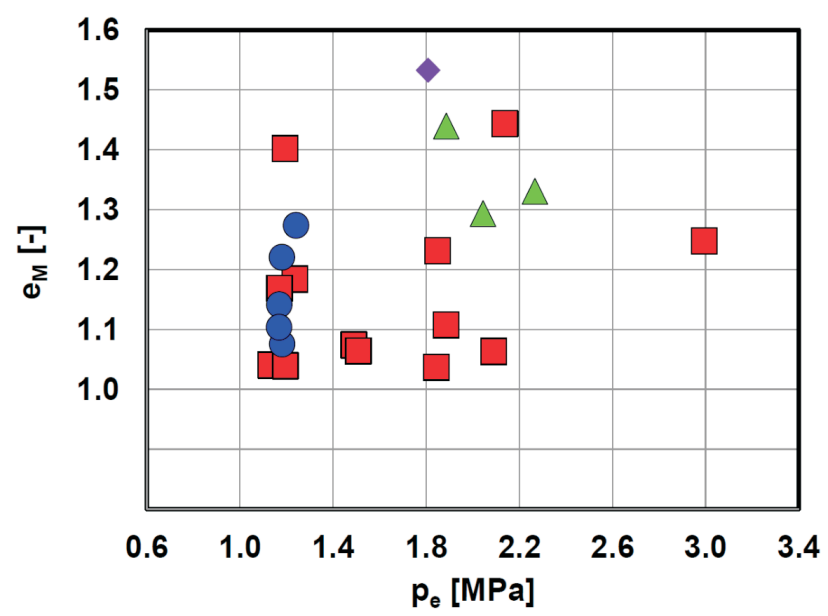

który jest wyrażony przez stosunek maksymalnego momentu obrotowego $\mathrm{M}_{\mathrm{o} \text { max }}$ do momentu obrotowego przy prędkości obrotowej maksymalnej mocy silnika $\mathrm{M}_{\mathrm{oN}}$ - wzór (1).

Wartość wskaźnika $\mathrm{e}_{\mathrm{M}}$ dla silników spalinowych będzie zawsze większa od jedności lub jej równa. Wartość zbliżona do jedności oznacza stałą wartość momentu w zakresie prędkości obrotowych od $\mathrm{M}_{\mathrm{o} \max }$ do $\mathrm{M}_{\mathrm{oN}}$.

Elastyczność prędkości obrotowej $\mathrm{e}_{\mathrm{n}}$ jest wskaźnikiem, który wyraża się stosunkiem prędkości obrotowej silnika mocy maksymalnej $n_{\mathrm{N}}$ do prędkości obrotowej występującej przy maksymalnym momencie obrotowym $n_{M}$ - wzór (2).

Jego wartość także nie może być mniejsza od jedności (wartość równa jeden oznacza, że moc maksymalna występuje przy takiej samej prędkości obrotowej jak maksymalny moment obrotowy). Im większa jest wartość tego wskaźnika, tym istnieje większy zakres prędkości użytecznej silnika.

Powyższe wskaźniki przedstawiono w odniesieniu do średniego ciśnienia użytecznego $\mathrm{p}_{\mathrm{e}}$. Silniki trzycylindrowe ZS, zastępujące silniki czterocylindrowe, uzyskują większe $\mathrm{p}_{\mathrm{e}}$, ale mniejsze wskaźniki elastyczności. W odniesieniu do silników ZI nowe jednostki trzycylindrowe uzyskują większe $\mathrm{p}_{\mathrm{e}}$ oraz $-\mathrm{w}$ niektórych przypadkach - większe wskaźniki $\mathrm{e}_{\mathrm{M}}$ (rys. 7a). Jest to spowodowane tym, że wolnossące jednostki o większej objętości mają płaski przebieg momentu obrotowego. Mimo tego, większość silników trzycylindrowych

b)

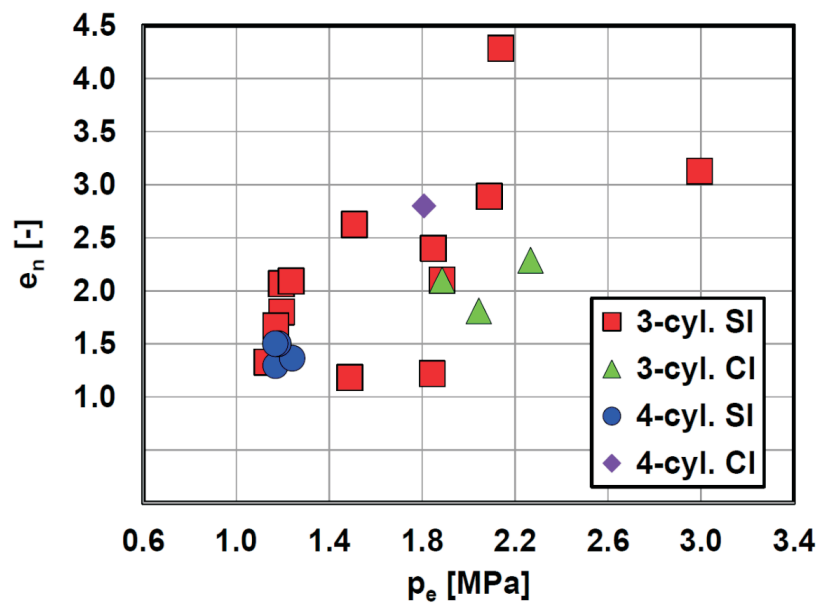

Fig. 7. Indexes of flexibility: a) torque, b) engine speed

Rys. 7. Wskaźniki elastyczności: a) momentu obrotowego, b) prędkości obrotowej

The index defining the total flexibility of the engine $e_{C}$ is the product of indexes of the torque flexibility and of the engine speed flexibility:

$$
\mathrm{e}_{\mathrm{C}}=\mathrm{e}_{\mathrm{M}} \cdot \mathrm{e}_{\mathrm{n}}
$$

Despite insignificant increase in the maximum values of the average effective pressures for 3-cylinder CI engines, significantly lower values of total flexibility in relation to the previous engines were obtained (Fig. 8a). For SI engines dzięki doładowaniu uzyskuje większe wskaźniki elastyczności prędkości obrotowej e $\mathrm{e}_{\mathrm{n}}$ - rys. $7 \mathrm{~b}$.

Wskaźnik określający całkowitą elastyczność silnika $\mathrm{e}_{\mathrm{C}}$ jest iloczynem wskaźników elastyczności momentu obrotowego oraz elastyczności prędkości obrotowej - wzór (3).

Mimo niewielkiego zwiększenia maksymalnych wartości średnich ciśnień użytecznych trzycylindrowych jednostek ZS, uzyskano znacznie mniejsze wartości elastyczności całkowitej w stosunku do poprzednich jednostek (rys. 8a). W odniesieniu do silników ZI duża ich liczba ma 
a)

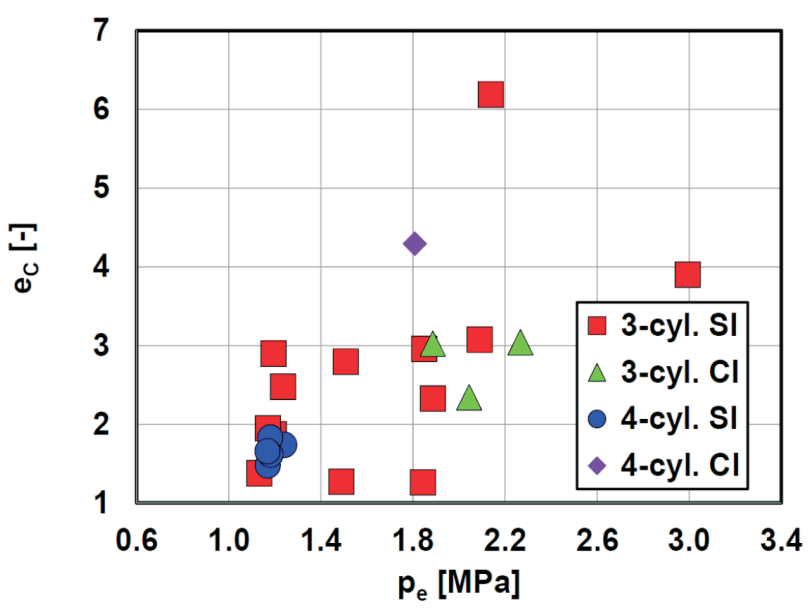

b)

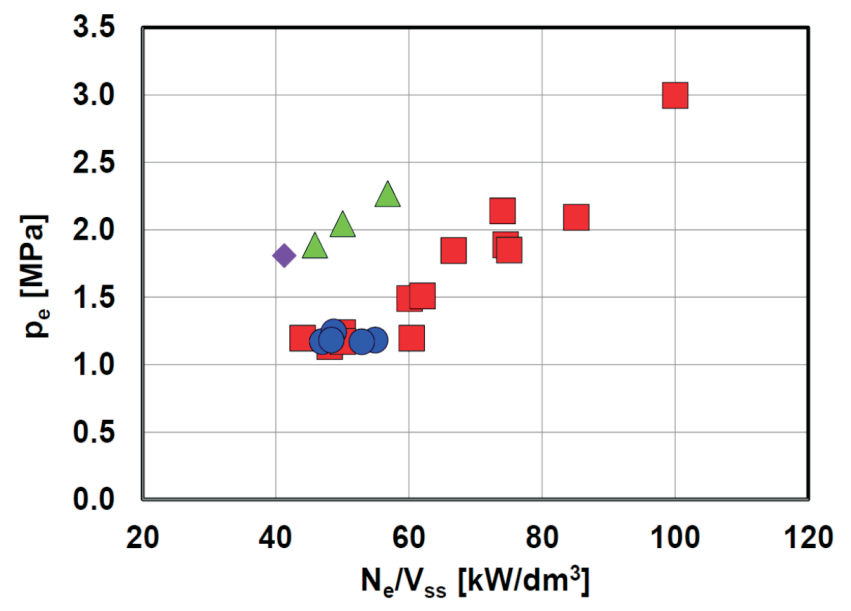

Fig. 8. Indexes of the total flexibility (a) and power/displacement ratio of the drive units (b)

Rys. 8. Wskaźniki elastyczności całkowitej (a) i wysilenia jednostek napędowych (b)

their majority showed higher $\mathrm{p}_{\mathrm{e}}$ or $\mathrm{e}_{\mathrm{C}}$ values, and about half of them had both indicators higher.

The tendency to design engines applying downsizing is noticeable in increasing power from specific engine displacement. Increasing the engine power results also in increased engine torque (represented by $p_{e}$ value). Analysis of the 4-cylinder engines indicates the possibility of increasing specific power without increasing power/ displacement ratio (varied engine displacement values determined the specific powers and similar values of $\mathrm{p}_{\mathrm{e}}$ ). In 3-cylinder engines this trend is proportional: along with increased specific power follows an increase of engine power/displacement ratio.

\section{Downsizing of combustion engines}

\subsection{Division of downsizing}

Currently there can be distinguish two types of downsizing: static or dynamic $[1,14,16]$. The first one involves reduction of engine dimensions by reducing engine displacement (through reduction of the number of cylinders). This method results in reduction of fuel consumption by up to $20 \%$. An inseparable part of the static downsizing process is the application of appropriate engine supercharging system in order to improve indexes of engine performance limited due to reduction of engine displacement. Application of the adequate supercharging system simultaneously increases the thermal and mechanical loads on the combustion engine systems, imposing on them increased requirements in terms of durability [2].

The reduction of the engine displacement by deactivating the cylinders characterizes the other - dynamic - type of downsizing [1]. It was applied in a few cases and mainly concerned the multi-cylinder engines ( $i \geq 6)$. Up to now it has been thought that the use of this type of downsizing is justified in engines with significant engine displacement, however the cylinder deactivation systems are also used e.g. in 4-cylinder engines installed in passenger cars [8]. większe $\mathrm{p}_{\mathrm{e}}$ lub $\mathrm{e}_{\mathrm{C}}$, a około połowa $\mathrm{z}$ nich ma większe oba wskaźniki.

Tendencja konstruowania silników z zastosowaniem downsizingu jest widoczna $\mathrm{w}$ zwiększaniu mocy $\mathrm{z}$ jednostki objętości silnika. Zwiększanie mocy silnika powoduje również skutki w postaci zwiększonego momentu obrotowego (reprezentowanego przez $\mathrm{p}_{\mathrm{e}}$ ). Analiza wskaźników pracy silników czterocylindrowych wskazuje na możliwości zwiększania mocy jednostkowej bez zwiększania wysilenia silnika (zróżnicowane objętości skokowe silników stanowiły o mocach jednostkowych i zbliżonych wartościach $\mathrm{p}_{\mathrm{e}}$ ). W silnikach trzycylindrowych tendencja ta jest proporcjonalna: wraz ze zwiększeniem mocy jednostkowej następuje zwiększenie wysilenia silnika.

\section{Downsizing silników spalinowych}

\subsection{Podzial downsizingu}

Obecnie możliwe jest wyróżnienie dwóch typów downsizingu: statycznego lub dynamicznego $[1,14,16]$. Pierwszy $\mathrm{z}$ nich polega na zmniejszeniu wymiarów silnika przez ograniczenie objętości skokowej (realizowanej przez zmniejszenie liczby cylindrów). Metoda ta powoduje oszczędności w zakresie zużycia paliwa do $20 \%$. Nieodłącznym elementem downsizingu statycznego jest odpowiedni system doładowania silnika powodujący zwiększenie wskaźników pracy silnika, ograniczonych przez zmniejszenie jego objętości skokowej. Zastosowanie odpowiedniego systemu doładowania zwiększa równocześnie obciążenia cieplne i mechaniczne układów silnika spalinowego, stawiając mu coraz większe wymagania wytrzymałościowe [2].

Zmniejszenie objętości skokowej silnika przez odłączanie cylindrów to drugi typ downsizingu - dynamiczny [1]. Był on stosowany bardzo rzadko i dotyczył głównie silników wielocylindrowych (i $\geq 6$ ). Dotychczas uważano, że jego stosowanie jest celowe w silnikach o dużych objętościach skokowych, jednak systemy wyłączania cylindrów znajdują zastosowanie m.in. w silnikach czterocylindrowych montowanych w samochodach osobowych [8]. 


\subsection{Mathematical description of downsizing}

Currently the concept of downsizing index $\mathrm{D}_{\mathrm{v}}$ is defined as the ratio of the difference in basic engine displacement $\left(\mathrm{V}_{\text {pods }}\right)$ and the engine displacement after downsizing $\left(\mathrm{V}_{\text {down }}\right)$ to the basic engine displacement $\left(\mathrm{V}_{\text {pods }}\right)$ :

$$
\mathrm{D}_{\mathrm{V}}=\frac{\mathrm{V}_{\text {podst }}-\mathrm{V}_{\text {down }}}{\mathrm{V}_{\text {podst }}}
$$

Formula (4) only gives information about the degree of engine displacement reduction. However, there is no information about the change in effective pressure $\left(\mathrm{p}_{\mathrm{e}}\right)$ of the engine after downsizing. Effective pressure $p_{e}$ is defined as:

$$
\mathrm{p}_{\mathrm{e}}=\frac{\mathrm{N}_{\mathrm{e}} \cdot \tau}{\mathrm{V}_{\mathrm{ss}} \cdot \mathrm{n}}
$$

where $\mathrm{N}_{\mathrm{e}}-$ is engine power at a given operating point, $\mathrm{V}_{\mathrm{ss}}$ - is engine displacement, $\mathrm{n}$ - is the engine speed, $\tau$ is the periodicity of combustion engine operation.

Use of formula (5) makes it possible to obtain information on the power/displacement ratio of the combustion engine after downsizing. It is therefore possible to define index of downsizing of the effective pressure $\left(\mathrm{D}_{\mathrm{p}}\right)$ as a ratio of the difference of average effective pressure of engine after downsizing $\left(\mathrm{p}_{\mathrm{e} \_ \text {down }}\right)$ and before downsizing $\left(\mathrm{p}_{\mathrm{e} \_ \text {pods }}\right)$ to the effective pressure of the engine after downsizing $\left(\mathrm{p}_{\mathrm{e} \text { down }}\right)$ :

$$
\mathrm{D}_{\mathrm{p}}=\frac{\mathrm{p}_{\mathrm{e} \_ \text {down }}-\mathrm{p}_{\mathrm{e} \_ \text {podst }}}{\mathrm{p}_{\mathrm{e} \_ \text {down }}}
$$

The values of the index obtained are within the range of positive and negative numbers. This means that regardless of the engine design, $\mathrm{D}_{\mathrm{p}}$ values are limited within a certain range of changes. This is important when comparing engine designs.

However, replacing the two above-mentioned indexes with one, indicating the actual benefits arising from the use of downsizing, seems to be a better solution. The resulting downsizing value was proposed as the geometric resultant value:

$$
\mathrm{D}=\sqrt{\mathrm{D}_{\mathrm{V}}^{2}+\mathrm{D}_{\mathrm{p}}^{2}}
$$

Acceptance of such index means that the target (asymptomatic) value of the downsizing index is $\mathrm{D}=1$, which in case of engines is not possible to obtain (Fig. 7a). This ensues from the inability to achieve value of one by any of the two downsizing indexes: engine displacement or effective pressure.

Indexes $\mathrm{D}_{\mathrm{v}}$ and $\mathrm{D}_{\mathrm{p}}$ obtain values below one. It may happen that the $\mathrm{D}_{\mathrm{p}}$ index takes value of zero (then $\mathrm{D}=\mathrm{D}_{\mathrm{v}}$ ). There are cases when both indicators take negative values. Negative values of the index of engine displacement downsizing mean that there has been an increase of the engine displacement. It might be accompanied by increase or decrease of the effective pressure. Such cases are shown in Figure 9b.

\subsection{Matematyczny opis downsizingu}

Obecnie używa się pojęcia wskaźnika downsizingu $\mathrm{D}_{\mathrm{v}}$ zdefiniowanego jako stosunek różnicy objętości skokowej silnika bazowego $\left(\mathrm{V}_{\text {pods }}\right)$ i objętości skokowej silnika po downsizingu $\left(\mathrm{V}_{\text {down }}\right)$ do objętości skokowej silnika bazowego $\left(\mathrm{V}_{\text {podss }}\right)$ - wzór (4).

Wyrażenie (4) pozwala jedynie na uzyskanie informacji o stopniu ograniczenia objętości skokowej silnika. Brak jest natomiast informacji o zmianie ciśnienia użytecznego $\left(p_{e}\right)$ silnika poddanego downsizingowi. Ciśnienie użyteczne $\mathrm{p}_{\mathrm{e}}$ zdefiniowane jest jako (5), gdzie: $\mathrm{N}_{\mathrm{e}}-$ moc silnika $\mathrm{w}$ danym punkcie pracy, $\mathrm{V}_{\mathrm{ss}}$ - objętość skokowa silnika, $\mathrm{n}$ - prędkość obrotowa silnika, $\tau$ - cykliczność pracy silnika spalinowego.

Wykorzystanie zapisu (5) pozwala na uzyskanie informacji dotyczącej wysilenia silnika spalinowego po downsizingu. Możliwe jest więc podanie wskaźnika downsizingu ciśnienia użytecznego $\left(D_{\mathrm{p}}\right)$ jako stosunku różnicy średniego ciśnienia użytecznego silnika po downsizingu $\left(\mathrm{p}_{\mathrm{e} \text { down }}\right)$ i przed $\operatorname{nim}\left(\mathrm{p}_{\text {e podst }}\right)$ do ciśnienia użytecznego silnika po downsizingu $\left(\mathrm{p}_{\mathrm{e} \_ \text {down }}\right)-$ wzór $(6)$.

Wartości uzyskanego wskaźnika znajdują się w zakresie liczb dodatnich oraz ujemnych. Oznacza to, że niezależnie od konstrukcji silnika wielkość $\mathrm{D}_{\mathrm{p}}$ przyjmuje wartości $\mathrm{z}$ określonego przedziału. Ma to znaczenie przy porównywaniu konstrukcji silników między sobą.

Lepszym wskaźnikiem wydaje się jednak zastąpienie dwóch powyższych jednym, wskazującym na rzeczywiste korzyści wynikające ze stosowania downsizingu. Wartość wynikowego downsizingu zaproponowano jako geometryczną wielkość wypadkową (7). Takie przyjęcie wskaźnika oznacza, że docelową (asymptotyczną) wartością wskaźnika downsizingu jest $\mathrm{D}=1$, która dla silników nie jest możliwa do uzyskania (rys. 9a). Wynika to z braku możliwości osiągnięcia jedności przez dowolny z dwóch wskaźników downsizingu: objętości lub ciśnienia użytecznego.

Wskaźniki $\mathrm{D}_{\mathrm{v}}$ oraz $\mathrm{D}_{\mathrm{p}}$ przyjmują wartości poniżej jedności. Może się zdarzyć, że wskaźnik $\mathrm{D}_{\mathrm{p}}$ przyjmie wartość równą zeru (wtedy $\mathrm{D}=\mathrm{D}_{\mathrm{v}}$ ). Istnieją przypadki, że oba wskaźniki przyjmą wartości ujemne. Wartości ujemne wskaźnika downsizingu objętościowego oznaczają, że nastąpiło zwiększenie objętości skokowej silnika. Może temu towarzyszyć zwiększenie lub zmniejszenie ciśnienia użytecznego. Przypadki takie przedstawiono na rysunku $9 \mathrm{~b}$.

\subsection{Downsizing statyczny}

Jak podano w rozdz. 5.1, downsizing statyczny polega na ograniczeniu wymiarów i objętości skokowej silnika, co realizuje się m.in. przez zmniejszenie liczby cylindrów. Duże znaczenie ma zastosowanie układów doładowania, dzięki którym możliwe jest zachowanie wskaźników pracy na niezmienionym poziomie. Prowadzi to do wzrostu wysilenia konstrukcji. Rysunek 10 przedstawia składowe wskaźników downsizingu dla rozpatrywanych jednostek napędowych.

$\mathrm{Z}$ analizy rysunku 10 wynika, iż poszczególne jednostki napędowe realizują przedmiotową koncepcję w odmienny sposób. Osiągnięcie danej wartości wskaźnika downsizingu może nastąpić zarówno przez znaczne ograniczenie objętości 
a)

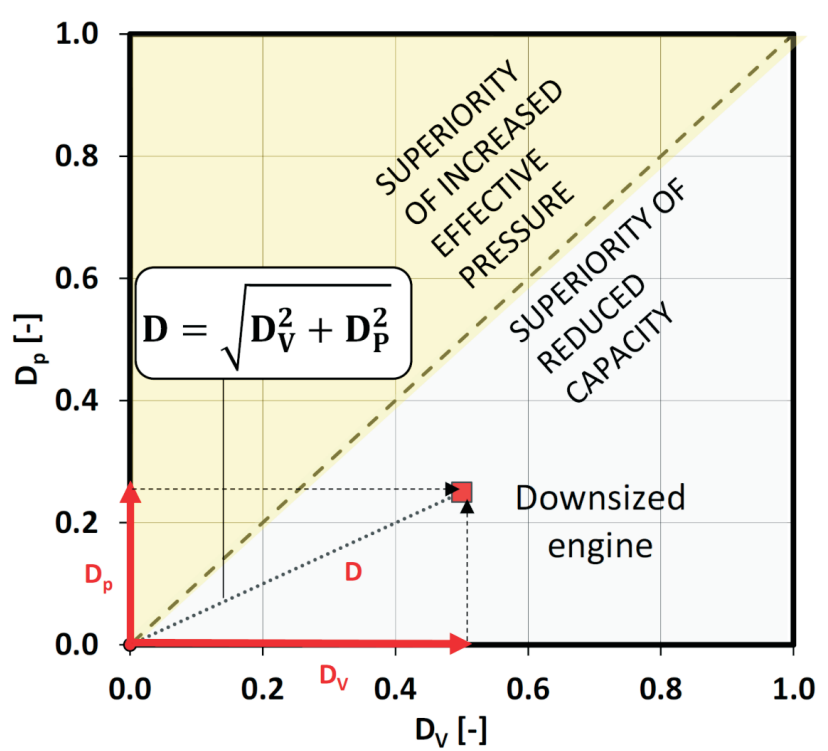

b)

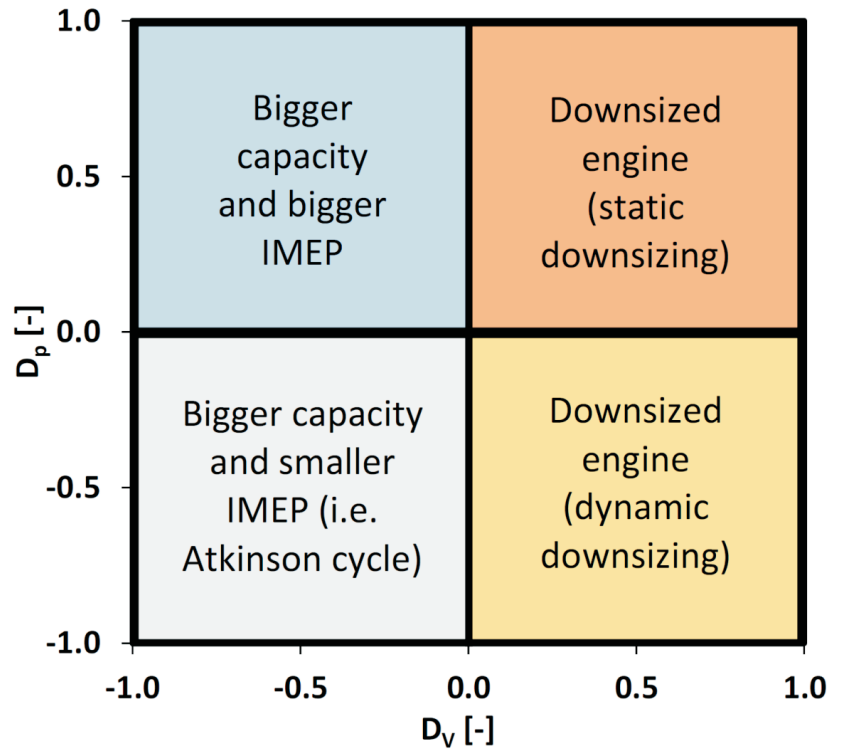

Fig. 9. Graphical way to determine the downsizing index (a) and its localization on the downsizing axes (b)

Rys. 9. Graficzny sposób wyznaczenia wskaźnika downsizingu (a) oraz jego umiejscowienie na osiach downsizingu (b)

\subsection{Static downsizing}

As mentioned in point 5.1, the static downsizing involves reduction of engine dimensions and engine displacement e.g. by reducing the number of cylinders. Of utmost importance is the use of supercharging systems so that it is possible to maintain the working parameters unchanged. This leads to an increase of power/displacement ratio for engine design. Figure 10 shows the components of downsizing indexes for the considered drive units.

Figure 10 shows that particular drive units implement the subject concept in a different way. Reaching a given value of downsizing can be carried out both by the significant reduction in the engine displacement at negligible growth of the power/displacement ratio (VW engines) and by a significant increase in the average effective pressure (and therefore of the downsizing index value of $D_{p}$ ) at relatively small reduction in the engine displacement (engine design by Renault). The limiting criterion of the components of the total downsizing index for a given design is an inclination angle of the straight line going through the origin of coordinates and a point defined by coordinates ensuing from the values of component indexes.

\subsection{Dynamic downsizing}

Dynamic downsizing, that is deactivation of cylinders, is implemented in multi-cylinder and 4-cylinder engines. Figure 11 shows ways of deactivating cylinders during engine operation. In the engines of W type (e.g. W12 by VW) it is possible to deactivate one of the cylinder banks (during operation of the 6-cylinder engine), in 8-cylinder engines are deactivated cylinders $2,3,5$ and 8 . In 6-cylinder engines it is possible to deactivate the combination of cylinder banks or only two cylinders. In the 4-cylinder engines the second and third cylinders are deactivated. skokowej silnika przy niewielkim wzroście wysilenia (silniki firmy VW), jak i przez znaczne zwiększenie średniego ciśnienia użytecznego (a zatem i wartości wskaźnika downsizingu $\mathrm{D}_{\mathrm{p}}$ ) przy niewielkiej redukcji objętości skokowej

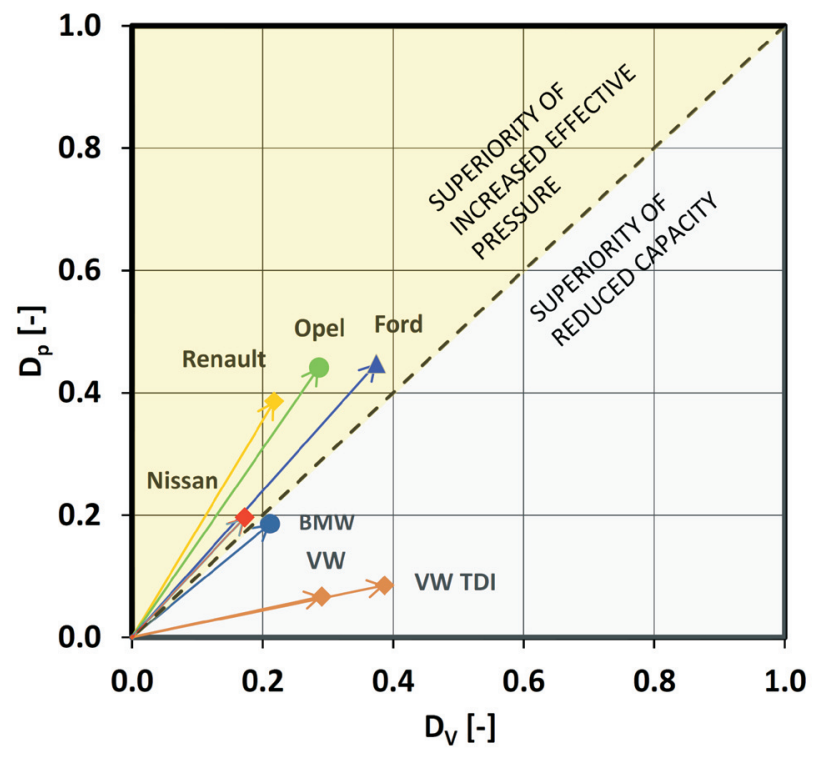

Fig. 10. The components of the total downsizing index for the considered engines

Rys. 10. Składowe całkowitego wskaźnika downsizingu rozpatrywanych silników

silnika (konstrukcja firmy Renault). Kryterium granicznym składowych całkowitego wskaźnika downsizingu danej konstrukcji jest kąt nachylenia prostej przechodzącej przez początek układu i punkt opisany współrzędnymi wynikającymi z wartości wskaźników składowych. 
Disabling cylinders in all types of presented engines starts with disabling ignition and fuel injection. The combustion chamber contains air that is trapped inside due to lack of opening and closing of the valves. These valves are closed by electromagnetically operated levers cooperating with appropriate cams on the camshaft.

An example of a modern design is Audi A3 fitted with 1.4 TFSI engine with system of cylinder deactivation, in which the average fuel consumption amounts to $4.7 \mathrm{dm}^{3} / 100 \mathrm{~km}$. In the NEDC test the use of the cylinder deactivation system resulted in fuel consumption reduced by approximately $0.4 \mathrm{dm}^{3} / 100 \mathrm{~km}$. Change in the driving style also enabled achieving $20 \%$ savings in fuel consumption $[8,20]$. The use of this engine in the Volkswagen Polo GT driving at a constant speed of $50 \mathrm{kph}$ on the third or fifth gear enables to reduce fuel consumption by approximately $1 \mathrm{dm}^{3} / 100 \mathrm{~km}$. When driving at a speed of $70 \mathrm{kph}$ on the fifth gear with enabled system of cylinder deactivation the fuel consumption is reduced by $0.7 \mathrm{dm}^{3} / 100 \mathrm{~km}[8,20]$.

In the 8-cylinder engine the system of cylinder deactivation (called AMG Cylinder Management) deactivates the second, third, fifth and eighth cylinder. The cylinder deactivation feature is available for a wide range of engine speeds: $800 \mathrm{rpm}$ to $3600 \mathrm{rpm}$. In 4-cylinder engine operation mode (V4), it enables obtaining up to $230 \mathrm{~N} \cdot \mathrm{m}$. For the engine speed of 3600 rpm the cylinder activation does not last longer than $30 \mathrm{~ms}$ $[9,20]$. The cylinder deactivation system is dependent on 16 hydraulic actuators placed in heads, disabling opening of the deactivated valves.

Having the specific characteristics of the engine performance and the engine operating areas during cylinders deactivation and on the basis of formulas (4)-(7) were determined indexes of the dynamic downsizing (Fig. 12). The analysis of the obtained indexes showed a substantial reduction in engine displacement - which was associated

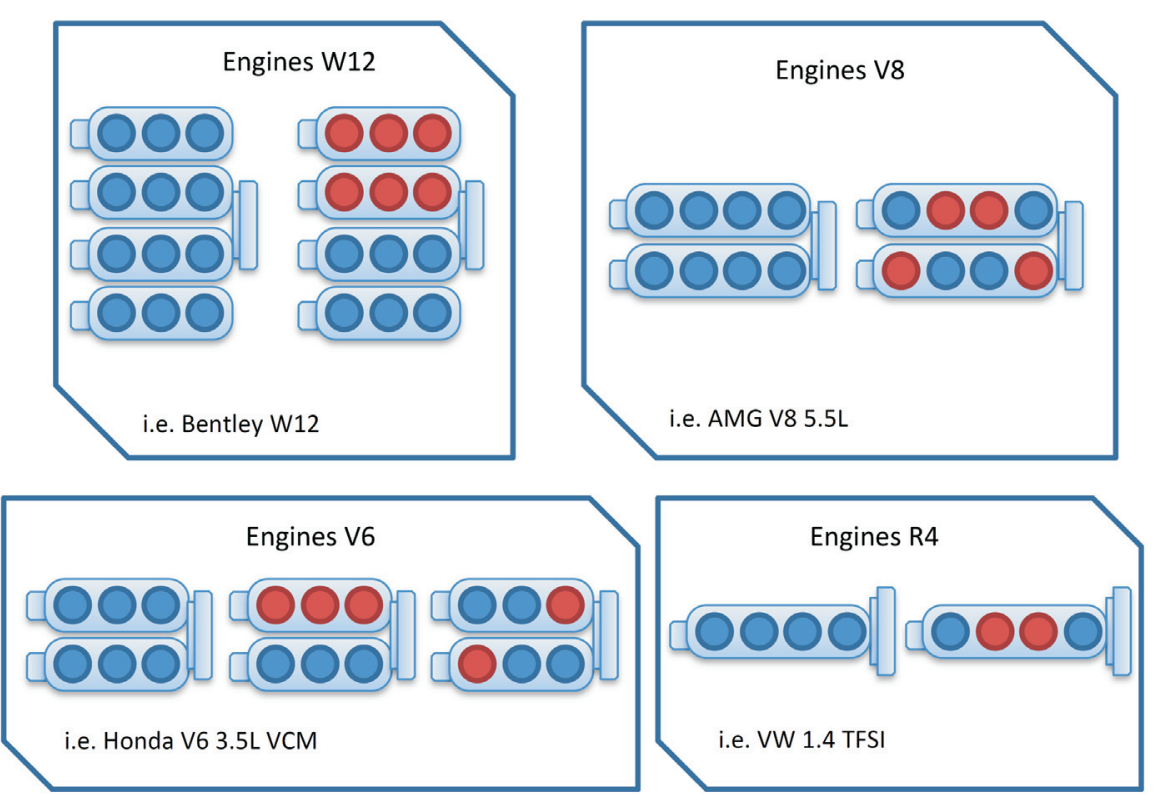

Fig. 11. Systems of dynamic downsizing in combustion engines [8, 9, 13, 24]

Rys. 11. Systemy downsizingu dynamicznego w silnikach spalinowych [8, 9, 13, 24]

\subsection{Downsizing dynamiczny}

Downsizing dynamiczny, czyli deaktywacja cylindrów, jest realizowany $w$ jednostkach wielocylindrowych oraz w silnikach czterocylindrowych. Na rysunku 11 przedstawiono sposoby wyłączania cylindrów podczas pracy silnika. W silnikach typu W (np. W12 firmy VW) możliwe jest wyłączenie jednego z rzędu cylindrów (praca silnika 6-cylindrowego), w silnikach 8-cylindrowych wyłączeniu ulegają cylindry $2,3,5$ oraz 8 . W silnikach 6-cylindrowych możliwa jest kombinacja wyłączenia rzędu cylindrów, a także tylko dwóch cylindrów. W silnikach 4-cylindrowych wyłączeniu podlegają cylindry drugi i trzeci.

Deaktywacja cylindrów we wszystkich typach przedstawionych silników rozpoczyna się od wyłączenia zapłonu i wtrysku paliwa. Komora spalania zawiera powietrze, które zostaje w niej zamknięte w wyniku braku otwierania i zamykania zaworów. Zawory te są zamknięte przez elektromagnetycznie uruchamiane dźwignie współpracujące z odpowiednimi krzywkami na wałku rozrządu.

Przykładem nowoczesnej konstrukcji może być Audi A3 wyposażone w silnik 1.4 TFSI z układem deaktywacji cylindrów, które uzyskuje średnie zużycie w paliwa na poziomie $4,7 \mathrm{dm}^{3} / 100 \mathrm{~km}$. W teście NEDC, wykorzystując system deaktywacji, uzyskano ograniczenie zużycia o około $0,4 \mathrm{dm}^{3} / 100 \mathrm{~km}$. Zmiana stylu jazdy umożliwia osiągnięcie $20 \%$ oszczędności zużycia paliwa $[8,20]$. Zastosowanie tego silnika w Volkswagenie Polo GT przy stałej prędkości jazdy $50 \mathrm{~km} / \mathrm{h}$ na trzecim lub piątym biegu pozwala na ograniczenie zużycia paliwa o około $1 \mathrm{dm}^{3} / 100 \mathrm{~km}$. Podczas jazdy z prędkością $70 \mathrm{~km} / \mathrm{h}$ na piątym biegu z aktywnym systemem wyłączania cylindrów uzyskuje się ograniczenie zużycia paliwa o $0,7 \mathrm{dm}^{3} / 100 \mathrm{~km}[8,20]$.

W silniku 8-cyl. układ deaktywacji cylindrów (nazywany AMG Cylinder Management) wyłącza drugi, trzeci, piaty i ósmy cylinder. Funkcja wyłączania cylindrów dostępna jest w szerokim zakresie prędkości obrotowej: od $800 \mathrm{obr} / \mathrm{min}$ do $3600 \mathrm{obr} / \mathrm{min}$. W trybie pracy silnika czterocylindrowego (V4) pozwala on na uzyskanie momentu obrotowego o wartości do $230 \mathrm{~N} \cdot \mathrm{m}$. Przy prędkości obrotowej $3600 \mathrm{obr} / \mathrm{min}$ aktywacja cylindrów nie trwa dłużej niż $30 \mathrm{~ms}$ [9, 20]. Za deaktywację cylindrów odpowiada system szesnastu hydraulicznych elementów wykonawczych umieszczonych w głowicach, uniemożliwiając otwieranie zaworów wyłączonych cylindrów.

Mając określone charakterystyki pracy silnika oraz pola pracy silnika podczas deaktywacji cylindrów, wyznaczono na podstawie wzorów (4)-(7) wskaźniki downsizingu dynamicznego (rys. 12). 
with deactivation of some cylinders. In this case the indexes of effective pressure downsizing $\left(\mathrm{D}_{\mathrm{p}}\right)$ obtained values below zero. This shows a reduction of effective pressure in these engines. Negative values allow for a broader interpretation of the dynamic downsizing, showing that it is not possible to achieve higher values of the engine $p_{e}$ when some of the cylinders are deactivated. This means that during dynamic downsizing the obtained values of $\mathrm{D}_{\mathrm{p}}$ should be less than zero. The equation defining the value of downsizing $\mathrm{D}$ is the root of the sum of the squares, so the sign in this case is of no actual importance.

In both analyzed cases the indexes of effective pressure downsizing obtained values below zero, $\mathrm{D}_{\mathrm{p}}=-0.25$ (VW engine) and $\mathrm{D}_{\mathrm{p}}=-0.17$ (Mercedes AMG engine) respectively. Taking these results into account in the total downsizing index the value of $\mathrm{D}=0.56$ for VW 1.4 TFSI engine is obtained. In case of the AMG engine the value of downsizing index amounted to $\mathrm{D}=0.53$.

a)

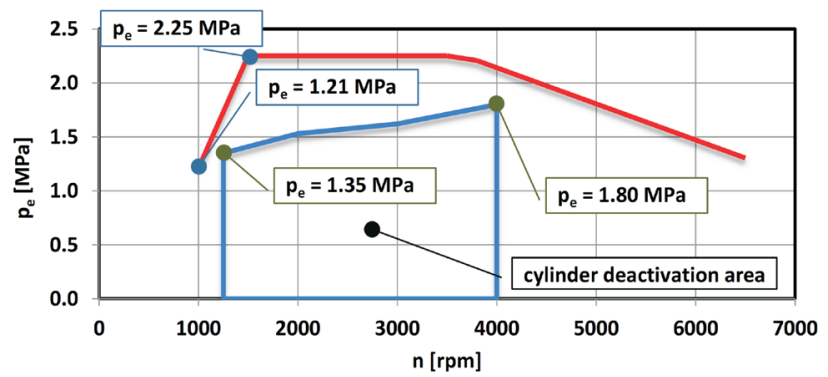

Analiza uzyskanych wskaźników pozwala na stwierdzenie znacznego zmniejszenia objętości - co wynika z wyłączenia części cylindrów z pracy. W tym przypadku uzyskano wskaźniki downsizingu ciśnienia użytecznego $\left(\mathrm{D}_{\mathrm{p}}\right)$ o wartościach poniżej zera. Świadczy to o zmniejszeniu ciśnienia użytecznego tych silników. Wartości ujemne umożliwiają szerszą interpretację downsizingu dynamicznego, z którego wynika, że nie jest możliwe otrzymanie większych wartości $\mathrm{p}_{\mathrm{e}}$ silnika podczas częściowego wyłączenia cylindrów z pracy. Oznacza to, że podczas downsizingu dynamicznego uzyskiwane wartości $\mathrm{D}_{\mathrm{p}}$ będą mniejsze od zera. Równanie wyznaczające wartość downsizingu D jest pierwiastkiem z sumy kwadratów, więc znak nie odgrywa tu istotnej roli.

W obu analizowanych przypadkach uzyskano wskaźnik downsizingu ciśnienia użytecznego poniżej zera: $\mathrm{D}_{\mathrm{p}}=-0,25$ (silnik VW) oraz $\mathrm{D}_{\mathrm{p}}=-0,17$ (silnik Mercedesa AMG). Uwzględnienie tych wyników w całkowitym wskaźniku downsizingu pozwala na uzyskanie wartości $\mathrm{D}=0,56$ dla

b)

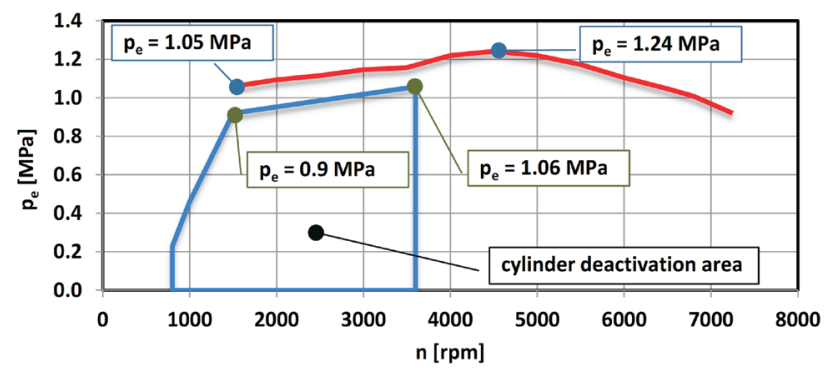

Fig. 12. The characteristics of the engines with cylinder deactivation system as examples of dynamic downsizing: a) 1.4 TFSI from VW, b) AMG V8 5.5 L $[8,9]$

Rys. 12. Charakterystyki silników z deaktywacja cylindrów jako przykłady downsizingu dynamicznego: a) 1.4 TFSI firmy VW, b) AMG V8 5.5 L [8, 9]

a)

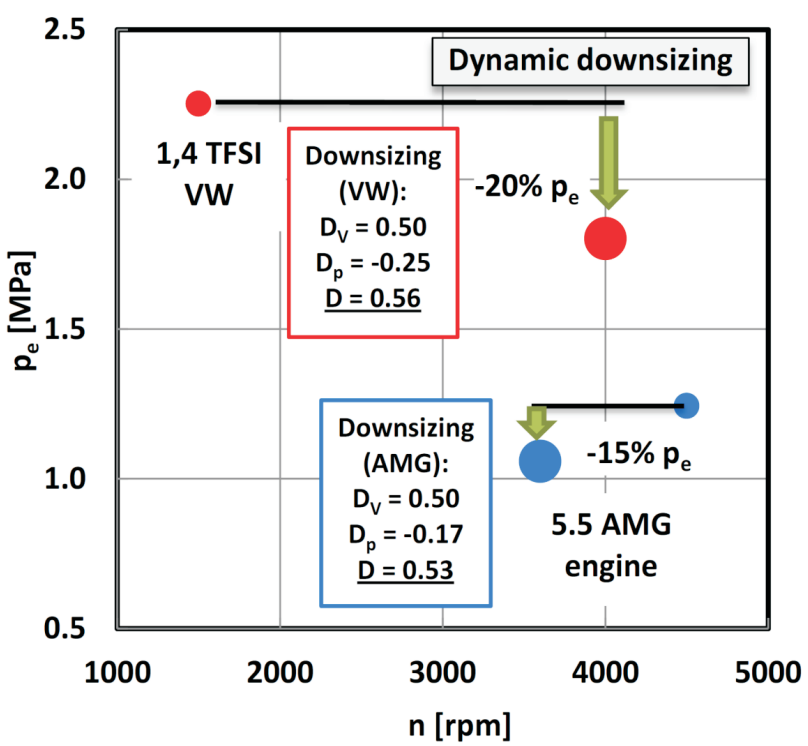

b)

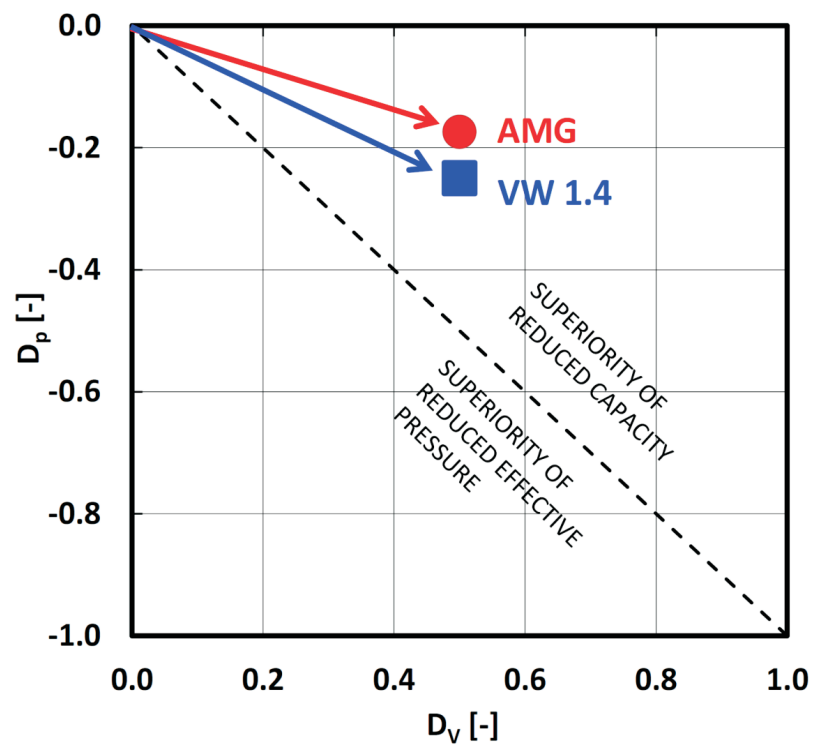

Fig. 13. Dynamic downsizing indexes: a) against the speed characteristics, b) against component coordinates of downsizing Rys.13. Wskaźniki downsizingu dynamicznego: a) na charakterystyce prędkościowej, b) we wspótrzędnych składowych downsizingu 
The data analysis for dynamic downsizing shows that the resultant indexes appear in the bottom right part of the nomogram shown in Figure 13a. This area has been additionally defined in Figure 13b, which takes into consideration the areas with an increased share of volumetric downsizing and areas with reduced values of effective pressure.

\section{Summary}

The most significant growth of effective pressure resulting from downsizing is observed for turbo-charged 3-cylinder engines replacing the normally aspirated engines. The largest increments for this parameter were observed for engines: BMW 1.5 DI TwinPower Turbo engines (increase of $\mathrm{p}_{\mathrm{e}}$ by $47 \%$ ), Opel 1.0 SIDI (78\%), Ford EcoBoost (81\%) and Renault 0.9 Turbo MPI (63\%). There can be also observed flatter characteristics of the effective pressure. This shows that the reduction on the number of cylinders does not adversely affect the obtained values of performance indexes. In most cases, the 3-cylinder engines obtain higher values of performance indexes compared to their 4-cylinder predecessors. Due to this the 3-cylinder engines have much higher power/displacement ratio.

Analyzing areas assigned to particular downsizing solutions (Fig. 14) it might be observed that in case of static downsizing it is possible to achieve a particular value of downsizing index through significant reduction in the engine displacement at negligible growth of the power/displacement ratio, as well as by a significant increase in the average effective pressure at relatively small reduction in the engine displacement. In case of dynamic downsizing obtaining particular values of downsizing index is possible by a substantial reduction in engine displacement - which is associated with deactivation of some cylinders. The obtained indexes of downsizing of the effective pressure below zero indicate reduction in effective pressure for the analyzed engines. Negative values allow for a broader interpretation of the dynamic downsizing, showing that it is not possible to achieve higher values of the engine $p_{e}$ during partial deactivation of some cylinders.

The presented methods of determining downsizing (defined in previous

silnika VW 1.4 TFSI. Dla silnika AMG uzyskano wartość wskaźnika downsizingu $\mathrm{D}=0,53$.

Analiza danych dotyczących downsizingu dynamicznego wskazuje na występowanie wynikowych wskaźników w dolnej prawej części nomogramu przedstawionego na rysunku 13a. Obszar ten został zdefiniowany na rysunku 13b, gdzie uwzględniono dodatkowo podział na obszary o zwiększonym udziale downsizingu objętościowego oraz o zmniejszonej wartości ciśnienia użytecznego.

\section{Zakończenie}

Największy przyrost ciśnienia użytecznego w wyniku zastosowania downsizingu zauważalny jest dla turbodoładowanych silników trzycylindrowych zastępujących silniki wolnossące. Największe wartości przyrostu tego parametru dotyczą silników: BMW 1.5 DI TwinPower Turbo (zwiększenie $\mathrm{p}_{\mathrm{e}}$ o 47\%), Opel 1.0 SIDI (78\%), Ford EcoBoost (81\%) oraz Renault 0.9 Turbo MPI (63\%). Zauważalny jest także bardziej płaski przebieg wartości ciśnienia użytecznego. Wynika z tego, iż ograniczenie liczby cylindrów nie wpływa negatywnie na osiągane wartości wskaźników pracy. W większości silniki trzycylindrowe mają większe wartości wskaźników pracy od swoich czterocylindrowych poprzedników. Powoduje to, iż silniki trzycylindrowe są znacznie bardziej wysilone.

Analizując obszary przypisane poszczególnym rozwiązaniom downsizingu (rys. 14), można stwierdzić, iż w odniesieniu do downsizingu statycznego możliwe jest uzyskanie określonej wartości wskaźnika downsizingu przez znaczne ograniczenie objętości skokowej silnika, przy niewielkim wzroście wysilenia, oraz przez wyraźne zwiększenie średniego ciśnienia użytecznego przy niewielkiej redukcji jego objętości skokowej.

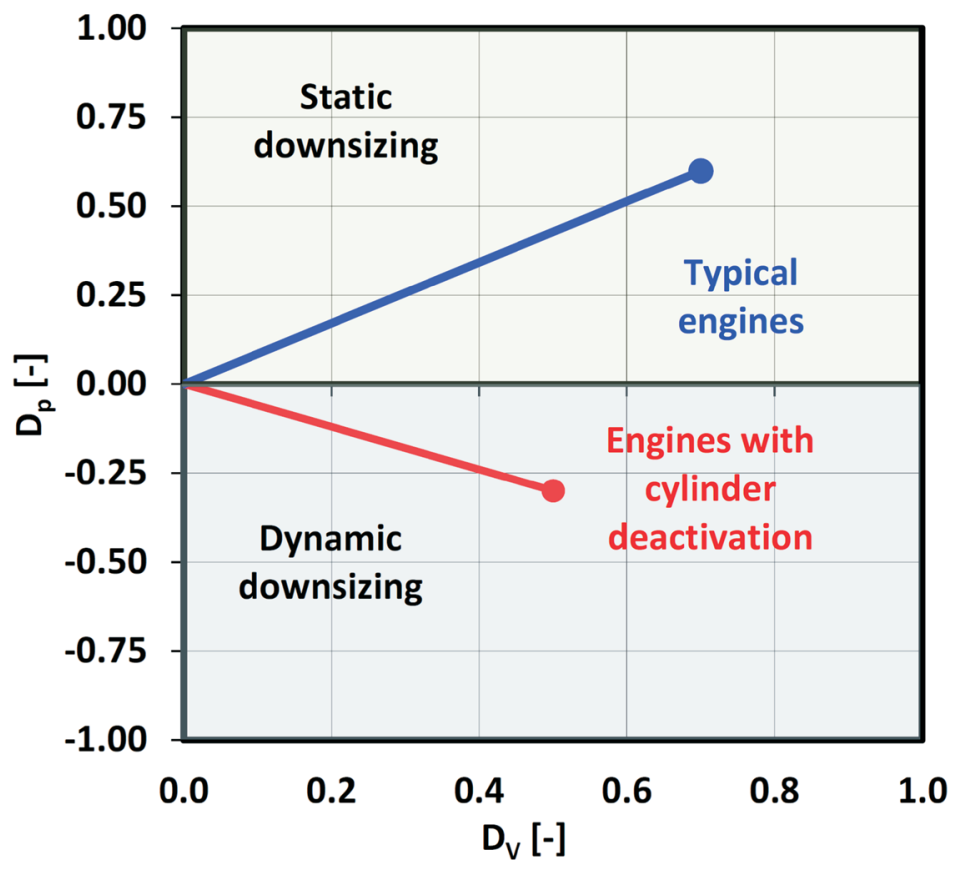

Fig. 14. Areas assigned to particular downsizing solutions including characteristic values

Rys. 14. Obszary przypisane poszczególnym rozwiązaniom downsizingu wraz z charakterystycznymi wielkościami
Natomiast dla downsizingu dynamicznego uzyskanie określonych wartości wskaźników downsizingu jest możliwe przez znaczne zmniejszenie objętości - co wynika z wyłączenia części cylindrów z pracy. Uzyskane wskaźniki downsizingu ciśnienia użytecznego o wartościach poniżej zera świadczą o zmniejszeniu ciśnienia użytecznego dla analizowanych silników. Wartości ujemne umożliwiają szerszą interpretację downsizingu dynamicznego, z którego wynika, że nie jest możliwe otrzymanie wartości $\mathrm{p}_{\mathrm{e}}$ większych podczas częściowego wyłączenia cylindrów z pracy.

Przedstawione sposoby określania downsizingu (zdefiniowanego we wcze- 
works of other authors) have been currently extended by mathematical and graphical dependencies. Such an approach significantly increases the possibility of utilizing downsizing in works on improvement of engine designs.

This article was financially supported within the project "Engineer of the Future. Improving the didactic potential of the Poznan University of Technology" - POKL.04.03.00-00-259/12, implemented within the Human Capital Operational Programme, co-financed by the European Union within the European Social Fund. śniejszych pracach różnych autorów) obecnie rozszerzono o matematyczne i graficzne zależności. Postępowanie takie znacznie zwiększa możliwości zastosowania downsizingu do prac konstrukcyjnych związanych z doskonaleniem konstrukcji silnikowych.

Publikacja powstała $w$ ramach realizacji projektu "Inżynier Przysztości. Wzmocnienie potencjału dydaktycznego Politechniki Poznańskiej.", nr POKL.04.03.00-00-259/12, wspólfinansowanego ze środków Unii Europejskiej w ramach Europejskiego Funduszu Spotecznego.

\section{Bibliography/Literatura}

[1] Brzeżański M., Śliwiński K.: Downsizing - nowy kierunek rozwoju silników samochodowych. Combustion Engines. 2004, 119(2), 3-11, ISSN-0138-0346.

[2] Bueschke W., Czajka J., Pielecha I., Cieślik W., Borowski P., Wisłocki K.: Doładowanie zakresowe nowoczesnych silników spalinowych. Logistyka 3/2013, 849-857, ISSN 1231-5478.

[3] Cieślik W., Borowski P., Pielecha I., Bueschke W., Czajka J., Wisłocki K.: Systemy recyrkulacji spalin we współczesnych konstrukcjach silnikowych. Logistyka 3/2013, 1118-1127, ISSN 1231-5478.

[4] EEA Report $\mathrm{CO}_{2}$ emissions performance of car manufacturers in 2012. www.eea.europa.eu. Publikacja danych 30.10.2012.

[5] Friedfeldt R., Zenner T., Ernst R., Fraser A.: Three-cylinder gasoline engine with direct injection. AutoTechnology Edition. 2012, 73(5), 4-11.

[6] int.smart.com (dated 5.02.2014).

[7] media.gm.com (dated 19.02.2014).

[8] Middendorf H., Theobald J., Lang L., Hartel K.: Der 1,4-LTSI-Ottomotor mit Zylinderabschaltung. Motortechnische Zeitschrift. 2012, 73(3), 186-193.

[9] m.mercedes-amg.com/pdf/eng/road_to_sustainability_en.pdf (dated 10.02.2014).

[10] Pielecha I.: Modeling of gasoline fuel spray penetration in SIDI engines. International Journal of Automotive Technology. 15(1), 47-55, 2014, doi:10.1007/s12239-014-0005-y.

[11] Pielecha I., Cieślik W., Borowski, Czajka J., Bueschke W.: The development of combustion engines for hybrid drive systems. Combustion Engines. 2014, 158(3), 23-35. ISSN 2300-9896.

[12] Reulein C., Schünemann E., Schwarz C., Wetzel M.: Thermodynamics of the BMW three-cylinder engine. MTZ Worldwide Edition. 2013, 5, 4-9.

Wojciech Cieślik, MEng. - postgraduate at the Faculty of Machines and Transportation of Poznan University of Technology.

Mgr inż. Wojciech Cieślik - doktorant na Wydziale Maszyn Roboczych i Transportu Politechniki Poznańskiej.

e-mail: wojciech.m.cieslik@doctorate.put.poznan.pl

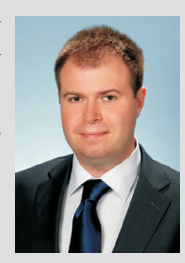

Jakub Czajka, DEng. - doctor at the Faculty of Machines and Transport of Poznan University of Technology.

Dr inż. Jakub Czajka - adiunkt na Wydziale Maszyn Roboczych i Transportu Politechniki Poznańskiej. e-mail: jakub.czajka@put.poznan.pl

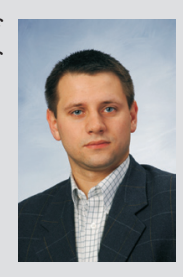

[13] Senapati U., McDevitt I., Hankinson A.: Vehicle refinement challenges for a large displacement engine with cylinder deactivation capability. SAE Technical Paper 2011-01-1678, 2011. doi:10.4271/2011-01-1678.

[14] Sroka Z.: Some aspects of thermal load and operating indexes after downsizing for internal combustion engine. Journal of Thermal Analysis and Calorimetry. 2012 110(1), 51-58, doi: 10.1007/s10973-011-2064-x.

[15] The Road Ahead, BorgWarner, 03.2012, www.borgwarner. com (dated 26.02.2014)

[16] Weissbäck M., Howlett M., Ausserhofer N., Krapf S. The efficiency engine - cost-effective alternative to downsizing. Combustion Engines. 2012, 149(2), 3-9, ISSN-0138-0346.

[17] www.atzonline.com (dated 26.02.2014).

[18] www.ford.com (dated 14.02.2014).

[19] www.gmpowertrain.com (dated 8.02.2014).

[20] www.greencarcongress.com (dated 6.02.2014).

[21] www.mahle-powertrain.com (dated 10.03.2014).

[22] www.psa-peugeot-citroen.com (dated 25.02.2014).

[23] www.renault.com (dated 21.02.2014).

[24] www.team-bhp.com (dated 03.02.2014).

[25] www.toyota-global.com (dated 10.02.2014).

Ireneusz Pielecha, DSc., DEng. - doctor at the Faculty of Machines and Transport of Poznan University of Technology.

Dr hab. inż. Ireneusz Pielecha - adiunkt na Wydziale Maszyn Roboczych i Transportu Politechniki Poznańskiej.

e-mail: ireneusz.pielecha@put.poznan.pl

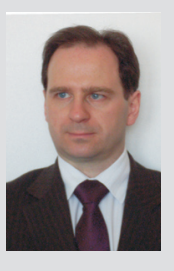

Przemysław Borowski, MEng. - postgraduate at the Faculty of Machines and Transport of Poznan University of Technology.

Mgr inż. Przemystaw Borowski - doktorant na Wydziale Maszyn Roboczych i Transportu Politechniki Poznańskiej.

e-mail:przemyslaw.t.borowski@doctorate.put.poznan.pl

Wojciech Bueschke, MEng. - postgraduate at the Faculty of Machines and Transport of Poznan University of Technology.

Mgr inż. Wojciech Bueschke - doktorant na Wydziale Maszyn Roboczych i Transportu Politechniki Poznańskiej. e-mail: wojciech.e.bueschke@doctorate.put.poznan.pl 